Bond University

Research Repository

\title{
Female audit committee members and their influence on audit fees
}

Aldamen, Husam; Hollindale, Janice; Ziegelmayer, Jennifer L.

Published in:

Accounting and Finance

DOI:

10.1111/acfi. 12248

Link to output in Bond University research repository.

Recommended citation(APA):

Aldamen, H., Hollindale, J., \& Ziegelmayer, J. L. (2018). Female audit committee members and their influence on audit fees. Accounting and Finance, 58(1), 57-89. https://doi.org/10.1111/acfi.12248

\section{General rights}

Copyright and moral rights for the publications made accessible in the public portal are retained by the authors and/or other copyright owners and it is a condition of accessing publications that users recognise and abide by the legal requirements associated with these rights.

For more information, or if you believe that this document breaches copyright, please contact the Bond University research repository coordinator. 


\title{
Female Audit Committee Members and Their Influence on Audit Fees
}

\begin{abstract}
:
We test the relationship between female representation on the audit committee and audit fees for 624 Australian companies in the year 2011. A positive relationship is found, leading to the conclusion that female presence on audit committees influences the quality of the external audit. Further, we find that gender is the significant audit committee characteristic in predicting audit quality, and that women on the audit committee strengthen the positive relationship between firm size and audit fees, and between risk and audit fees. Conversely, we find that female representation dampens the positive relationship between complexity and audit fees.
\end{abstract}




\section{Introduction}

The structure and effectiveness of the board of directors and its subcommittees is perhaps one of the most recognized forms of corporate governance (Connelly, Hoskisson, Tihanyi, and Certo, 2010; De Lacy, 2005). In particular, the audit committee, viewed by many as the most important board subcommittee (Kesner, 1988; Klein, 1998; Xie, Davidson and DaDalt, 2003), has wide-ranging authority over the financial accountability and reporting process. It appoints, compensates, and oversees the work and independence of the external auditor. Furthermore, the audit committee reviews the general purpose financial reports, provides oversight of the internal control and risk management processes and pre-approves all auditing and non-auditing services (Aldamen, 2010; Australian Institute of Company Directors, 2011; Klein, 1998). Certain characteristics, such as independence, expertise and accounting education are critical to the audit committee’s effectiveness (Abbott, Parker, and Peters, 2004; Klein, 2002; Krishnan, 2005). However, more recently, gender diversity on boards and committees has gained recognition as one of the factors that increases effectiveness. Female directors on boards can have influence over the level of risk aversion, conservatism when making decisions, and the monitoring of management (Gul, Hutchinson and Lai, 2013; Thiruvadi and Huang, 2011). In fact, participation of female directors in subcommittees, such as the audit committee, is not merely a gender equality issue, per se, but a governance issue that requires thorough consideration.

Prior literature provides evidence to support the relationship between female representation on boards of directors and firm-specific variables such as value (Carter, Simkins, and Simpson, 2003), stock returns (Campbell and Minguez-Vera, 2010), earnings management (Arun, Almahrog, and Aribi, 2015), earnings quality (Srinidhi, Gul, and Tsui, 2011), financial restatements (Abbott, Parker, and Presley, 2012), and continuous disclosure compliance (Chapple and Truong, 2015). Female directors exercise better monitoring of management 
(Adams and Ferreira, 2009) and the likelihood of corporate failure is reduced when female directors sit on boards (Burgess and Tharenou, 2002). Firms with female CEOs report more conservative earnings (Ho, Li, Tam, and Zhang, 2015) and are more conservative in estimating discretionary accruals (Barua, Davidson, Rama, and Thiruvadi, 2010; Peni and Vähämaa, 2010).

The relationship between firm performance and board gender diversity has also been studied extensively over the years and while positive relationships have been found (for example, Erhardt, Werbel, and Shrader, 2003; Hutchinson, Mack, and Plastow, 2015), results have certainly been mixed. Adams and Ferreira (2009) show that females have better patterns of attendance at board meetings than males and that gender-diverse boards exercise more effort in their monitoring activities, however, they find that women directors have a negative impact on firm performance. In Denmark where female board representation is very low, gender diversity has no impact on firm performance (Rose, 2007). Using U.S. data, Carter et al. (2010) also find no evidence to link board gender diversity with financial performance, and Chapple and Humphrey (2014) arrive at a similar result examining board gender diversity in their Australian study. These inconsistent findings leave the question of whether gender diversity at the board level improves organizational performance undecided and, despite a large body of literature, no definitive conclusions have been reached.

However, a recent meta-analysis of 140 studies between 1997 and May 2014, covering 144 independent samples, and representing over 90,000 firms in 35 countries was conducted by Post and Byron (2015). They sought confirmation that female board members positively affect firm performance. They found a positive relationship between accounting returns and female board representation, and further, that this relationship was greater in countries with stronger stakeholder protection mechanisms. Their findings about the relationship between female board members and market performance, while slight, were positive in countries where 
greater gender parity exists but negative in countries with low gender parity. Consequently, it seems appropriate to conclude that female board members do enhance company financial performance but not necessarily company stock market performance.

However, little is known about the impact of gender diversity on the audit committee and proxies of external audit outcomes such as audit fees. Prior studies focus on how female directors influence the effectiveness of the audit committee (Carter, D’Souza, Simkins, and Simpson, 2010; Sun, Liu, and Lan, 2011; Thiruvadi and Huang, 2011). They also examine the relationship between various aspects of corporate governance and audit fees (Bliss, 2011; Boo and Sharma, 2008; Carcello, Hermanson, Neal, and Riley, 2002; Chan, Liu, and Sun 2013; Griffin, Lont, and Sun, 2008; Larcker and Richardson, 2004). However, a specific link between female representation on the audit committee and audit fees is largely unexplored. To date, two studies have been identified in which this relationship is directly investigated. Ittonen, Miettinen, and Vähämaa (2010) examine the relationship between audit committee gender diversity and audit fees in S\&P 500 firms. They find that committees with more than one female member or with a single female member serving as chair report lower audit fees. These findings are attributed to increased internal monitoring and improved communication on the part of female members, which lowers perceived audit risk and reduces the need for external audit services. In a conference paper, Sultana and Rahman (2016) followed a line of enquiry similar to ours. They found that audit committees with female representation have higher audit fees and higher abnormal audit fees.

We propose a positive relationship between gender diversity on the audit committee and audit fees. Consistent with the demand-side perspective (Abbott, Parker, Peters, and Raghunandan, 2003; Goodwin-Stewart and Kent, 2006; Turley and Zaman, 2007), we contend that effective committees will require more services from the external auditor. We base our premise on the notion that female audit committee members will seek higher quality audit 
information, which in turn will require more audit services, thereby increasing audit fees. Furthermore, we propose that female directors on the audit committee moderate the relationships between audit fees and inherent situational factors such firm size, risk and audit complexity. Thus, we expect that when these situational factors are low, the presence of female directors on the audit committee creates a supply-side effect whereby audit fees decrease due to a reduction of audit risk. However, when the inherent situational factors are high, the presence of females on the audit committee will not reduce audit risk adequately and demandside effects will result in increased fees.

The importance of this topic stretches beyond bridging the gap in the literature to include the consideration of the rising trend in world markets where gender diversity on boards of directors is encouraged and in some instances, expected. Some countries (e.g., Australia, Canada, and the United Kingdom) recommend gender diversity as part of corporate governance best practices (ASX Corporate Governance Council, 2010; Financial Reporting Council, 2014; Ontario Securities Commission, 2013). However, other countries (e.g., Belgium, France, India, Italy, Norway and Spain) have enacted a quota system whereby it is mandatory to maintain a certain number of female directors on the board (Kamonjoh, 2014). Given this increased attention, it is imperative to understand the corporate governance implication of gender diversity on boards of directors and their subcommittees. This study not only contributes to the extant literature by examining the thinly researched topic of the relationship between female representation on the audit committee and audit fees, it also offers world markets empirical evidence that will influence the debate on the importance of gender diversity.

We test the relationship between female representation on the audit committee and audit fees for 624 non-financial Australian companies in the year 2011. This year is significant in the Australian context due to the Australian Securities Exchange (ASX) Corporate Governance Council (2010) recommendation that corporate boards should establish measurable objectives 
to become more diverse in terms of gender and to report on the proportion of women employees in the company. It is expected that after 2010 companies subject to these recommendations will make an effort to increase female participation on their boards and audit committees. Thus, our study examines this issue at a critical turning-point in the composition of audit committees.

Using OLS regression, we confirm our first proposition by demonstrating a positive relationship between the presence of females on the audit committee and the fees charged by the auditor. This finding provides support for the demand-side argument that female representation on audit committees results in a committee that requires more services from the external auditor, resulting in higher audit fees. Additionally, we use interaction terms to examine our second proposition regarding the moderating role of female audit committee members on the relationship between the three situational characteristics (firm size, firm risk, and audit complexity) and audit fees. We find that in the presence of low size and low risk, there is support for the supply-side argument in that fees are lower when there are females on the audit committee. In the presence of high size and high risk, we find support for the demandside argument in that fees are higher when women serve on the audit committee. However, in examining audit complexity, we find the opposite. Female representation dampens the positive relationship between complexity and audit fees, resulting in higher fees for low complexity audits and lower fees in high complexity audits when women are on the committee.

The remainder of the paper proceeds as follows. Section Two provides a review of prior literature, presents a theoretical link between female representation on the audit committee and audit fees, and states our hypotheses. Section Three details the research design. Section Four describes the results of the analysis. Finally, Section Five offers a discussion of the results and the conclusion to the paper in which contributions and limitations of our study are described.

\section{Literature Review, Theoretical Foundation, and Hypotheses}

The board of directors and subcommittees such as audit committees are chief mechanisms 
that play an important monitoring role on behalf of shareholders. From an agency theory perspective, corporate governance mechanisms provide independent substantive oversight of management's activities, which should protect shareholder interests. Including female board members on the audit committee not only adds diversity, but strengthens the monitoring efforts of the board (Adams and Ferreira, 2009). However, institutional theory provides a different view to female representation on boards and subcommittees. According to the theory, firms' concern for their perceived legitimacy prompts their adoption of various policies and procedures that conform to other organizations' actions (Beasley, Carcello, Hermanson, and Neal, 2009; Cohen, Krishnamoorthy, and Wright, 2008; DiMaggio and Powell, 1983; Meyer and Rowan, 1977). Dunn (2012) proposes that rather than focusing on operational improvements, firms that emulate others' practices do so for reasons of survival. They wish to avoid their activities being challenged, and thus create a perception of lower uncertainty and risk, and consequently gain greater access to key resources (Dunn, 2012). Others contend that mimicking behavior is mostly for ceremonial purposes and some research has questioned whether the very existence of audit committees is largely for ceremonial purposes rather than for effective monitoring of financial reporting (Beasley et al., 2009; Cohen et al., 2008). Whatever the reason, the incidence of females on corporate boards and subcommittees continues its upward trend as companies follow the lead of others and conform to regulatory requirements in increasing gender diversity in corporate governance.

Long before corporate governance principles and recommendations were established, researchers asserted that the scope or extent of an external audit is directly influenced by the audit committee (Carcello et al., 2002; Collier and Gregory, 1996; Goodwin-Stewart and Kent, 2006; Kalbers and Fogarty, 1993). This is a credible notion as the audit committee possesses and exercises powers with regard to supporting and promoting audit quality and in determining the scope and adequacy of the external audit. Audit committees also have rights to obtain information from internal and external auditors and to make recommendations to the board on issues that include the appointment or dismissal of external auditors (Australian Institute of 
Company Directors, 2011). Thus, the audit committee holds a position of power and influence over the quality of audit demanded from the external auditor. Further, the general belief is that effective audit committees influence the level of audit coverage and thus audit fees. Given the authority assigned to an audit committee in performing its oversight role of the financial reports, this is reasonable and is supported by research evidence (Abbott et al., 2003; Beasley et al., 2009; Carcello et al., 2002; Hay, Knechel, and Ling, 2008; Turley and Zaman, 2007).

The study of gender diversity of audit committees in relation to external audit fees is relatively new and only two studies have been identified that address this topic. In one study, Ittonen et al. (2010) find that external audit fees are lower when there are women on the audit committee and suggest this is due to women enhancing the monitoring activities of the audit committee. However, this is inconsistent with the findings of Gul, Srinidhi, and Tsui (2008) which explores female board members' impact on audit effort. Gul et al. (2008) found that audit fees are higher with female board membership and suggest that female membership influences higher demand for audit effort. The Sultana and Rahman (2016) conference paper also found higher audit fees in the presence of female audit committee members but did not explicitly link this to female audit committee members demanding more audit effort.

\subsection{Characteristics of Female Board Members}

Archival researchers do not generally have access to private information regarding board decision-making and this makes the dynamics of mixed gender representation in the boardroom difficult to observe and measure. As a result, research has often focused on identifying differences between the characteristics of board members of each gender. A plethora of literature in the psychology and business disciplines examines differences in attitudes, characteristics, and decision-making across gender. These studies show that women possess certain qualities that differ from, or are of different levels than, those possessed by men and find this works to the company's benefit in various ways. For example, women's 
communication capabilities are more effective (Wood, Polek, and Aiken, 1985) and female directors are more inclined to ask questions that men would not ask (Konrad, Kramer and Erkut, 2008). Board oversight is improved with female participation (Srinidhi et al., 2011; Thomas and Ely, 1996). This increases board independence which in turn has a positive influence on firm value (Carter et al., 2003).

Females working as a group may provide better solutions to a problem (Wood et al., 1985). Wood et al. (1985) conducted a psychology experiment and found that while all male groups generated more solutions to a problem, higher quality solutions were generated by female groups. A positive influence on firm performance is evident when the board consists of a higher percentage of women rather than a single female director (Campbell and MínguezVera, 2008). Konrad et al. (2008) determined that two women on a board are better than one because they have a larger impact on the board than a single woman and that three women (the “magic number”) are better than two. They suggest that, from a group dynamics perspective, a critical mass of three or more females might have a noticeable bearing on boardroom content and dynamics. Furthermore, they found that more varieties of topics are discussed when three or more women are on the board and that this helps the board to focus on longer-term sustainable performance. Joecks, Pull and Vettner's (2013) research of German firms found that it takes a critical mass of three female directors before higher firm performance is achieved. It is noted, however that Germany has a dualistic corporate governance system and different results might be observed in different corporate governance systems.

Female board presence disrupts groupthink and promotes a slower pace of decisionmaking (Abbott et al., 2012; Daily, Dalton and Cannella, 2003; Robinson and Dechant, 1997). Females have a higher quality decision-making capability and are more likely to challenge the conventional decision making processes because they feel significantly less constrained by the use of rules, regulations and other traditional ways that dominate the typical normative 
reasoning of male decision-making (Bart and McQueen, 2013). Women also are more likely to engage in participative decision-making (Mano-Negrin and Sheaffer, 2004). Further, female directors are said to be better directors as they are significantly more likely to consider the interests of multiple stakeholders and consistently make fairer decisions when competing interests are at stake (Bart and McQueen, 2013). These practices promote better corporate governance.

Numerous studies have also found that women have a lower preference for risk (e.g., Barber and Odean 2001; Charness and Gneezy, 2012; Dwyer, Gilkeson, and List, 2002; Hallahan, Faff, and McKenzie, 2004; Jianakoplos and Bernasek, 1998; Johnson and Powell, 1994; Powell and Ansic, 1997; Thiruvadi and Huang, 2011; Watson and McNaughton 2007), and make more conservative decisions than men (Byrnes, Miller, and Schafer, 1999; Levin, Schneider, and Gaeth, 1988; Powell and Ansic, 1997; Schubert, 2006; Watson and McNaughton, 2007). Conservatism in risk preferences is likely to lower the potential for bankruptcy. Furthermore, Lord Davies’ 2011 report on women board members (Davies, 2011), referred to a study by a Leeds University Business School that found that having one female director reduced the chances of bankruptcy by $20 \%$ and this was reduced even further if there were two or three females on the board.

It is not surprising that, given the qualities women are likely to bring to the corporate boardroom and their contributions to corporate governance, they are taking part in important subcommittees such as the audit committee. However, despite the important role of this committee and calls for greater diversity in audit committee composition, research in this area is fairly limited. Thiruvadi (2012) finds that gender diverse audit committees are more likely to display diligence by meeting more often. Attributes associated with women such as a questioning nature, communication skills, commitment to duty, and fair and morally consistent decision making are essential to effective corporate governance and are likely to increase the 
effectiveness of an audit committee in implementing board policy and governance. Virtanen's (2012) finding that female board members take more active roles on the board supports the supposition that females bring the same qualities to their subcommittee positions and influence the extent of internal and external monitoring demanded by the audit committee. Given that women are also more conscientious (Schmitt, Realo, Voracek and Allik, 2008), and take their responsibilities more seriously (Fondas and Sassalos, 2000), it is plausible that they would also demand more detailed and extensive audits. Consistent with the increased audit fees found to be correlated with female board membership (Gul, Srinidhi, and Tsui, 2008) and female audit engagement partners (Ittonen and Peni, 2012), it is reasonable to assume that female representation on the audit committee may also lead to increased audit fees.

\subsection{Hypotheses}

Given the traits demonstrated by women in corporate governance positions, it seems plausible that female presence on the audit committee would increase its effectiveness. This is in line with a Thiruvadi and Huang (2011) study, which suggests a positive link between female presence on the audit committee and audit quality. Female attributes of diligence, independence, conservatism, and risk-aversion demonstrated in previous studies suggest that women audit committee members would demand a higher level of audit quality and require more detailed work by the external auditor. This increased audit effort would result in higher audit fees than those for companies with all male audit committees.

We posit that in a gender diverse audit committee, a higher quality audit will be demanded increasing the level and scope of services required of external auditors and manifesting in higher audit fees. Consistent with the preponderance of the results of studies of audit committee effectiveness, we hypothesize the following:

$H_{1}$ : There is a positive relationship between female presence on the audit committee and audit fees. 
Previous literature postulates two approaches to explain the effect of audit committee effectiveness on audit fees: the demand-side and the supply-side arguments. Demand-side arguments contend that more effective audit committees command more external audit effort, driving up audit fees (Carcello et al., 2002; Gul et al., 2008; Zaman, Hudaib, and Haniffa, 2011). On the other hand, supply-side arguments (Abbott et al., 2003; Munro and Stewart, 2011; Stewart and Munro, 2007) posit that effective audit committees better monitor the financial reporting process and communicate better with the auditors, thereby reducing audit risk. High-risk audits result in higher fees by requiring more audit procedures. When effective audit committees reduce the audit risk, the extent of audit work from the auditor's perspective is reduced, thus lowering audit fees (Krishnan and Visvanathan, 2009).

Studies investigating the impact of audit committee effectiveness on audit fees take one approach or the other, treating the supply-side and demand-side arguments as competing theories and findings exist to support each. Krishnan and Visvanathan (2009) acknowledge that these are complementary rather than competing theories yet they do not approach them as such. We posit that the conflicting findings in the past are a result of not considering the interplay of these two approaches and we propose a unified model of the impact of audit committee effectiveness on audit quality that incorporates both approaches (see Figure 1).

$<$ Figure 1 about here $>$

Consistent with the demand-side argument, the model proposes a positive relationship between audit committee effectiveness and audit effort, which in turn is positively related to audit fees. In addition, the model incorporates the supply-side argument by proposing a negative relationship between audit committee effectiveness and audit risk. Audit risk has a direct, positive relationship with audit fees due to risk premiums (Jiang and Son, 2015) and auditor experience (Cahan and Sun, 2015) necessary in risky audits. Risk also impacts audit fees indirectly via a positive relationship with audit effort since risky audits require more effort. 
Thus, we contend audit fees are driven by both audit effort and degree of audit risk. Furthermore, each of these is influenced by the effectiveness of the committee.

While an effective committee may reduce the control risk component of audit risk, the inherent risk component is unaffected and remains. Inherent risk is a result of situational factors such as firm size and firm risk, as well as audit complexity, which are specific to the organization and its business environment. The inherent risk for each organization is different and in some situations, an effective committee may mitigate the risk sufficiently to effect lower audit fees even in the face of increased audit effort. However, in other situations, the risk may be so great that even a high degree of audit committee effectiveness may not counteract the necessity for extensive and expensive audit procedures.

Several conditions contribute to the level of inherent risk, and subsequently the external audit work required. The seminal study by Simunic (1980) shows that firm size and risk, as well as audit complexity are primary factors that explain audit fees. Later studies by Francis and Simon (1987) and Simon and Francis (1988) further support the importance of those factors. The underlying argument is that as firm size increases so does the number of transactions that need to be audited. Furthermore, companies that are risky stand to undergo bankruptcy, which might subject the auditor to reputational damage or litigation. This will encourage the audit firm to conduct more thorough investigations to protect themselves from this possibility. A similar argument is also made for firms that maintain complex operations. Those firms will most likely require extensive reporting and record keeping. As a result, the auditor will need to allocate additional time and resources to examine those records (Ittonen et al., 2010; Loukil, 2014). In each of these cases, we propose that inherent risk will be high, increasing overall audit risk.

We propose that in a mixed gender audit committee, a higher quality audit will be demanded in these high-risk situations increasing the level and the scope of services required 
of external auditors and will manifest in higher audit fees (demand-side argument). Simultaneously, greater monitoring of managerial behavior will occur when females are present on the audit committee; this will reduce control risk (supply-side argument). However, we contend that the reduction in control risk will not be sufficient to mitigate the increase in audit risk created by the higher inherent risk. Thus, we expect that when inherent risk is high, fees will be higher when there are females on the audit committee than for all-male audit committees.

On the other hand, while we expect committees with female members to demand more audit effort than all-male committees, when inherent risk factors are low we expect audit committees with females to request fewer procedures than they do in high risk situations. In addition, female presence on the committee will effect increased monitoring and better communication with the auditors, resulting in decreased control risk. The combination of decreased control risk with already low inherent risk will result in audit risk low enough to mitigate the demand for additional procedures. Thus, we expect that when inherent risk is low, fees will be lower when there are females on the audit committee than for all-male audit committees. Therefore, we hypothesize:

H2: Female presence on the audit committee will strengthen the positive relationship between inherent risk factors and audit fees.

\section{Research Design}

\subsection{Sample Selection}

The initial sample includes all companies with audit committees listed on the Australian Securities Exchange in the year 2011. The year 2011 has a special significance since it was the first year companies were expected to report the diversity of their boards of directors including female representation on the board and subcommittees (ASX Corporate Governance Council, 2010). After excluding companies from the financial sector and companies with missing 
information, the final sample comprises 624 companies. The data used in the study come primarily from notes in the annual reports while other information is obtained from Thomson Reuter’s BoardRoom, SandP’s Capital IQ and Morningstar’s FinAnalysis databases.

\subsection{Measurement of variables}

Consistent with prior studies, the dependent variable, audit fees, is measured as the natural log of fees paid to auditors (Carcello et al. 2002; Loukil, 2014). We use the variable AUD_FEES to designate audit fees. The independent variable female representation on the audit committee, represented by FEM_CODE, is a dichotomous variable that indicates whether females are present on the audit committee or not (Abbott et al., 2012; Ittonen et al., 2010). In line with previous studies, variables for characteristics related to audit committee effectiveness are included. These are independence, experience and education (Abbott et al., 2003; Ittonen et al., 2010; Vafeas and Waegelein, 2007). Audit committee independence, AC_INDP, is measured as the proportion of audit committee members that are independent and nonexecutive. Audit committee experience, $A C_{-} E X P$, is operationalized as the proportion of audit committee members that have board experience. Audit committee education, $A C \_E D U$, is measured as the proportion of audit committee members with an accounting or finance degree or who have an accounting-related professional certification (e.g., CPA, CMA or CFA).

We also include variables representing the firm's situational audit risk factors: firm size, firm risk, and audit complexity (Carcello et al., 2002; Kane and Velury, 2004; Lee and Mande, 2005; Loukil, 2014; Simunic, 1980). Firm size, SIZE, is measured as the natural log of total assets. Leverage, $L E V$, is the proxy for firm risk which is measured as total debt divided by total assets. Complexity, INVREC, is measured as total inventory and receivables divided by total assets.

Finally, we control for four additional firm specific characteristics: the type of auditor, firm performance, liquidity and industry. The variable BIG4 is used to proxy the type of auditor. 
It equals one if the auditor is a Big Four accounting firm and zero otherwise. Performance, $R O A$, is measured as the return on assets which is earnings before interest and tax divided by total assets. Liquidity, $C R$, is represented by the current ratio which is measured as total current assets divided by total current liabilities. Industry is controlled for by using industry fixed effects. This is conducted by the use of $\mathrm{K}$ - 1 industry dummy variables.

\subsection{Method}

The study uses univariate, bivariate, and multivariate analyses to test the hypotheses presented in the previous section. Univariate analysis is carried out through ANOVA to test whether the means of the variables are different for companies that have female representation on the audit committee relative to those that do not. Additionally, we conduct ANOVA on all variables to determine whether differences exist based on the presence of firm size, risk, and audit complexity. Bivariate analysis is carried out in the form of Pearson's correlation analysis. Multivariate analysis is conducted via the estimation of the following OLS regression model:

$$
\begin{aligned}
A U D \_F E E S & =\beta_{0}+\beta_{1} F E M \_C O D E_{i}+\beta_{2} A C \_I N D P_{i}+\beta_{3} A C \_E X P_{i}+\beta_{4} A C \_E D U_{i}+\beta_{5} S I Z E_{i} \\
& +\beta_{6} L E V_{i}+\beta_{7} I N V R E C_{i}+\beta_{8} B I G 4_{i}+\beta_{9} R O A_{i}+\beta_{10} C R+\text { Industry fixed effects } \\
& +\varepsilon_{i}
\end{aligned}
$$

where

$$
\begin{array}{ll}
\text { AUD_FEES }= & \text { Natural log of audit fees for firm } i . \\
\text { FEM_CODE }= & \text { One if at least one audit committee member is female and zero otherwise } \\
& \text { for firm } i . \\
= & \text { Proportion of audit committee members that are independent and } \\
& \text { nonexecutive for firm } i . \\
= & \text { Proportion of audit committee members that have board experience for } \\
& \text { firm } i . \\
A C \_E X P_{i} & = \\
& \text { Proportion of audit committee members with a finance or accounting } \\
A C \_E D U_{i}= & \text { Negree (or have CPA, CMA or CFA) for firm } i . \\
S I Z E_{i}= & \text { Total debt to total assets for firm } i . \\
L E V_{i}
\end{array}
$$


$\operatorname{INVREC}_{i} \quad=$ Inventory and receivables divided by total assets for firm $i$.

$B I G 4_{i}=$ One if the auditor for firm $i$ is a Big Four auditor and zero otherwise.

$R O A_{i} \quad=$ Earnings before interest and tax divided by total assets for firm $i$.

$C R_{i} \quad=$ Total current assets divided by total current liabilities for firm $i$.

Industry fixed

effects $\quad=\mathrm{K}-1$ industry dummy variables.

In line with prior studies, we expect that factors such as firm size, firm risk, and audit complexity play an important role in determining audit fees (Carcello et al., 2002; Kane and Velury, 2004; Lee and Mande, 2005; Loukil, 2014; Simunic, 1980). Two methods are used to examine the impact of these factors.

The first method is to split the sample into three pairs of subsets based on the median values of the three inherent risk factors mentioned above. The sample is split into small and large sized companies; low and high risk companies; and low and high complexity audits. The model is then estimated for each subset separately and the results are examined to identify differences in the subset pairs.

The second method is to introduce interaction terms to the model. The first interaction term, SIZE_INTR, is FEM_CODE multiplied by SIZE. This interaction term is used only when testing the impact of female committee representation in the presence of company size. The second interaction term, RISK_INTR, is FEM_CODE multiplied by RISK. This interaction term is used only when testing the impact of female committee representation in the presence of company risk. The third interaction term, INVREC_INTR, is FEM_CODE multiplied by INVREC. This interaction term is used only when testing the impact of female committee representation in the presence of complexity.

\section{Results}

\subsection{Descriptive Statistics}


The descriptive statistics for all the companies in the sample are reported in Panel A, Table 1 . The mean for audit fees is 5.031 and the standard deviation is 0.514 . Approximately fifteen percent (15.4\%) of the companies have at least one female member on the audit committee. These results indicate that female representation is fairly modest and that the vast majority of companies do not have female board members on the audit committee. Reported next are the variables representative of characteristics related to the effectiveness of the audit committee. The mean proportion of independent audit committee members is $58.6 \%$; the mean proportion of members with board experience is $47.0 \%$; however, the mean proportion of members with accounting educational credentials is only $25.9 \%$. These percentages indicate that the composition of audit committees varies across the three effectiveness proxies. The mean natural log of total assets, which represents company size, is 7.816. The risk variable suggests that, on average, $40 \%$ of assets are financed through debt. On average, receivables and inventory represent $18 \%$ of total assets and almost $50 \%$ of all companies have a Big Four auditor. Average performance, measured by return on assets, is $-29.2 \%$. Finally, the mean for the liquidity variable shows that current assets are more than six times greater than current liabilities.

(Table 1 about here)

Panel B, Table 1, shows the descriptive statistics for companies that have females on the audit committee $(n=96)$. The overall results suggest that these companies have certain characteristics that distinguish them from other companies. The mean for audit fees is 5.439 and the standard deviation is 0.615 . The mean proportion of independent audit committee members for these companies is $61.8 \%$, while the mean proportion of members with board experience is $52.4 \%$. The mean proportion of members with accounting educational credentials is $24.1 \%$. The mean for company size, risk, complexity, having a Big Four auditor, profitability and liquidity are $8.150,0.352,0.291,0.720,-0.0006$, and 4.947 respectively. However, the 
statistical significance in these differences requires the use of ANOVA analysis.

Recall that 96 (15.4\%) companies from our sample of 624 have female audit committee representation. Table 2 provides more detailed information. When gender diversity is present on the audit committee, the number of female audit committee members ranges from one to four. While only one company (1\%) in the sample has four female audit committee members, two companies (2\%) have three females, thirteen (14\%) have two females, and the overwhelming majority (80 companies or $83 \%$ ) have only one female member.

(Table 2 about here)

Table 2 also provides a breakdown of female representation based on situational factors The majority of females represented on the audit committee are found in large, high risk, and high complex companies. In terms of company size, $22 \%$ of large size companies have females on the audit committee as opposed to only $9 \%$ for small size companies. For risk, these percentages are $19 \%$ and $12 \%$ respectively. As for complexity, companies with females on the audit committee represent $17 \%$ and $14 \%$ of high and low complexity companies respectively.

The largest number of companies with females on the audit committee is found in the Materials industry $(n=20)$. However, since the Materials industry is the largest amongst all other industries, the percentage of female representation in this industry relative to other industries is in fact the lowest (9\%). On the other hand, seven out of 18 companies in the Utilities industry have females on the audit committee, thus making it the industry with most female presentation (39\%).

\subsection{ANOVA Results}

ANOVA is used to assess variations in the means for the variables based on the presence or absence of female members on audit committees. However, there is an issue of unequal sample sizes as the number of audit committees that have female members is much fewer than the number of audit committees that do not. As a result, we use Brown-Forsythe 
ANOVA to address this concern. The results reported in Table 3 suggest that there is a significant difference in the means for AUD_FEES across the two subsets $(p<.01)$. This indicates that audit fees are higher for companies that have female representation on the audit committee relative to other companies. ANOVA results also show that the means for SIZE, $B I G 4$, and $R O A$ are significantly different for companies that have female audit committee members versus committees that do not $(p<.01)$. This shows that firms with females on the audit committee tend to be larger, to have a Big Four auditor, and to be more profitable than firms with all-male audit committees. Additionally, the results in Table 3 show that there is a significant difference in the means for $C R(p<.05)$. This indicates that firms with females on the audit committee tend to be more liquid than companies without female audit committee members.

(Table 3 about here)

ANOVA is also conducted to assess differences in variable means in the presence of company size, company risk and audit complexity as shown in Table 4. Sample sizes are equal in this analysis as the total sample is split at the median. The results demonstrate that there are significant differences in means for AUD_FEES, FEM_CODE, AC_INDP, BIG4, ROA, and $C R(p<.01)$ based on firm size. Audit fees are significantly higher for larger companies. Furthermore, larger companies are more likely to have female audit committee members, independent audit committee members, a Big Four auditor, higher profitability and less liquidity. Table 4 also presents ANOVA results for company risk. The results indicate that significant differences exist for means of AUD_FEES, AC_INDP, SIZE, INVREC, BIG4 and $C R(p<.01)$ as well as FEM_CODE and AC_EDU $(p<.05)$. These findings suggest that higher audit fees are paid by companies that have greater risk relative to other companies. Furthermore, female presence on the audit committee, higher levels of independence and education on the audit committee, larger size, higher audit complexity, having a Big Four 
auditor and less liquidity are found in riskier companies relative to other companies.

(Table 4 about here)

A similar ANOVA is conducted to assess the differences in the variable means in the presence of audit complexity. The ANOVA results for the means of high versus low complexity firms are presented in Table 4. These results indicate that the means for AUD_FEES, SIZE, $L E V, B I G 4$ and $C R$ are significantly different based on the complexity of the audit as measured by INVREC $(p<.01)$. This suggests that audit fees are higher for more complex audits relative to other audits. Furthermore, firms with more complexity are larger, have higher risk, and tend to retain a Big Four auditor. However, the mean liquidity is much lower for high complexity firms versus low complexity firms.

\subsection{Correlation Analysis Results}

The correlation results are reported in Table 5. The presence of females on the audit committee is positively correlated with firm size $(p<.01)$, complexity $(p<.05)$, and having a Big Four auditor $(p<.01)$. There is a negative correlation between audit committee independence and expertise on the audit committee $(p<.01)$. However, expertise on the audit committee and accounting education of audit committee members are positively correlated $(p<.01)$. Company size is negatively correlated to risk $(p<.01)$ and liquidity $(p<.01)$, while it is positively correlated to having a Big Four auditor $(p<.01)$ and profitability $(p<.01)$. Risk is negatively correlated to profitability $(p<.01)$, and liquidity $(p<.01)$. Although the correlation coefficients are relatively small, thus dismissing concerns for multicollinearity, collinearity diagnostics in the form of Variance Inflation Factors (VIF) is undertaken before conducting the regression analysis.

(Table 5 about here)

\subsection{Regression Results}

OLS regression is used to examine the impact of female representation on the audit 
committee on the amount of audit fees paid. The VIF results indicate that there is no multicollinearity in the data. Results of the regression analysis are presented in Models 1 through 4 in Table 6. Model 1 shows the regression results without the industry fixed effects while Model 2 includes the eight industry variables. Models 3 and 4 replace the variable FEM_CODE with FEM_NUM (number of females on the audit committee) as a robustness test to the main variable. However, Model 3 excludes the industry variables while Model 4 includes them.

The results in Model 1 explain approximately 69\% of the variance in audit fees. As expected, the analysis shows that the presence of a female on the audit committee is associated with higher audit fees $(p<.01)$. This is consistent with prior studies that adopt a demand-side perspective to the relationship between audit fees and audit committee characteristics (Abbott et al., 2003; Goodwin-Stewart and Kent, 2006; Turley and Zaman, 2007; Zaman et al, 2011). However, our findings are in conflict with Ittonen et al. (2010) who find a negative relationship between audit fees and females on the audit committee. The three other variables related to audit committee effectiveness did not demonstrate significant relationships at the .05 level. However, company size (SIZE), company risk (LEV), audit complexity (INVREC) and engaging a Big Four auditor (BIG4) are positively related to audit fees $(p<.01)$. Liquidity $(C R)$ is the only significant control variable that is negatively related to audit fees $(p<.01)$. The results in Model 2, which include industry fixed effects, echo the results reported in Model 1. Although the explanatory power of the model increased to almost $72 \%$, the statistical significance for the coefficient of audit independence (AC_INDP) and complexity (INVREC) dropped drastically. It is important to note that, all other things being equal, AUD_FEES are lower for firms in the energy and materials sectors than in the reference industry sector $(p<$ .01). The results reported under Models 3 and 4 mirror those reported under Models 1 and 2. This suggests that there is no difference between the two proxies for female representatives on 
the audit committee. As a result, the remaining analysis is conducted with the original variable, FEM_CODE.

(Table 6 about here)

The relationship between audit fees and female representation is also examined by modeling the interaction of female audit committee participation with company size, risk, and audit complexity. Table 7 presents the results of investigating the interplay of female presence on the audit committee and firm size. The first approach is to split the sample into small SIZE and large SIZE subsets based on the value being below and above the median of SIZE. The results show that there is no relationship between female representation on the audit committee and audit fees for small firms. Additionally, none of the other audit committee effectiveness variables have a significant relationship with audit fees for small firms. However, company risk, engaging a Big Four auditor and profitability are positively related to audit fees $(p<.01)$. For large firms, female representation on the audit committee is positively related to audit fees $(p<.01)$. However, the only two other control variables that are related to audit fees at a significance level of .05 or less are firm risk and use of a Big Four auditor. The adjusted $\mathrm{R}^{2}$ values of 0.326 and 0.435 for the small and large company samples respectively indicate the model does not explain much of the variance when applied to the subsamples. This is not unexpected as the most important predictor, SIZE, is not included in the model for this analysis.

(Table 7 about here)

The second approach is to assess the relationship between audit fees and female representation on the audit committee using interaction terms. It is clear from Table 7 that the model accounts for over $72 \%$ of the variance when applied to the entire sample and an interaction term calculated as the product of SIZE and FEM_CODE is included in the model. The interaction term is positive and significant $(p<.01)$ indicating that female presence on the audit committee strengthens the positive relationship between firm size and audit fees. To 
better understand this interaction, Figure 2 presents a visualization of the relationship by plotting the interaction using points one standard deviation above and below the mean. The figure demonstrates that in smaller firms, fees are lower when there are women on the audit committee but in large firms the opposite occurs.

$<$ Insert Figure 2 about here $>$

The same procedures are used to examine how female audit committee membership interacts with risk. As shown in Table 8 for both low and high $L E V$ firms, female participation on the audit committee is significantly related to audit fees $(p<.05)$. For the low $L E V$ subsample, audit committee education is the only audit committee characteristic that is significantly related to audit fees $(p<.10)$, and it is negative. However, none of the audit committee effectiveness variables are related to audit fees for the high $L E V$ subsample. In terms of firm characteristics, size, use of a Big Four auditor, and profitability are significant predictors for both subsamples $(p<.01)$. However, complexity is only a significant factor for high $L E V$ firms $(p<.01)$.

(Table 8 about here)

Table 8 further indicates that the model accounts for over $72 \%$ of the variance when the entire sample is examined using an interaction term calculated as the product of $L E V$ and FEM_Code. The interaction term is positive and significant $(p<.05)$ which suggests that the presence of females on the audit committee strengthens the positive relationship between company risk and audit fees. Examination of the interaction plot (see Figure 3) shows that when risk is low, female presence on the audit committee results in lower fees; however, when risk is high and females are present on the committee, fees are higher.

$<$ Insert Figure 3 about here $>$

Finally, Table 9 presents the results of the regression model in the presence of complexity. For low INVREC firms, audit fees is positively related to female presence on the 
audit committee $(p<.05)$. Audit committee independence, firm size, firm risk, and having a Big Four auditor are also significantly related to audit fees $(p<.01)$, while profitability is negatively related at the .05 significance level. The adjusted $\mathrm{R}^{2}$ for the low INVREC subsample is 0.660 . Results of the regression on the high INVREC subsample indicate that the presence of females on the committee is again positive and significantly related to audit fees $(p<.10)$. However, while firm size, risk, and engaging a Big Four audit firm are significant predictors $(p<.01)$, audit committee independence is not. The adjusted $\mathrm{R}^{2}$ for the high INVREC subsample is 0.768 .

(Table 9 about here)

Table 9 reports the results of regression analysis on the full sample using an interaction term in the model that is the product of INVREC and FEM_CODE. This results in an adjusted $\mathrm{R}^{2}$ of .729 and demonstrates that the interaction term is significant and negatively related to audit fees $(p<.01)$. This suggests that female representation on the audit committee dampens the positive relationship between audit complexity and audit fees. Examination of the interaction plot (see Figure 4) shows almost no change in audit fees between low and high complexity when there are no females on the audit committee. However, when females are on the committee, fees are higher in low complexity situations than they are in high complexity situations.

$<$ Figure 4 about here $>$

\section{Discussion and Conclusion}

The results of the study provide solid support for the importance of gender diversity on the audit committee. The examination of female representation on the audit committee and audit fees shows a positive relationship which supports the demand-side argument for audit effort. This is to say that audit committees with female members require more services from the external auditor, thus incurring higher audit fees. However, the interaction of female 
presence on the committee with factors that create audit risk provides critical findings that explain gender diversity and audit fees. In the presence of low size and low risk, we find support for the supply-side argument in that fees are lower when there are women on the audit committee. This supports our proposition that the impact of females on the monitoring process sufficiently reduces risk to outweigh demands for increased audit effort. On the other hand, in the presence of high size and high risk, we find support for the demand-side argument in that fees are higher when women are on the audit committee. In these situations, the necessity of additional effort demanded by the circumstances outweighs the improved monitoring effected by women on the audit committee.

However, in examining audit complexity, we find the opposite. In situations where there is audit complexity, female representation dampens the positive relationship between complexity and audit fees. Consistent with the demand-side argument, in low complexity situations audit fees are higher when there are women on the audit committee than when there are none. However, in the presence of high audit complexity, audit fees are lower when a female member is on the audit committee than when there are no females. This negative interaction is an intriguing difference from the interaction effects found for size and risk. We suggest that this may demonstrate the female demand for more external audit effort in the low complexity situation and that high complexity is better managed by increased monitoring activity than are size and risk; however, we recognize that further research is required to unravel this perplexity.

We acknowledge that our findings and implications for the present study are subject to several limitations and these provide opportunities for further research. Firstly, our sample comprises ASX firms; thus, our empirical analysis is limited to publicly-traded Australian firms. Our findings are not necessarily generalizable to firms outside of Australia. Secondly, our study was confined to the year 2011 which was selected because it was the first year 
corporate governance regulations required ASX companies to report on their diversity policies (ASX Corporate governance Council, 2010). Studying a later period may yield different results. Given that early adopters of board and subcommittee diversity policies may have been motivated to do so by reasons other than consideration of females' expertise and qualities, an extended research period may be useful. This would determine how female representation on the audit committee affects audit fees over time and perhaps also determine whether appointments are merit-based or are largely tokenism based on adhering to corporate governance regulations. Thirdly, our factors for audit risk followed Simunic (1980) and were based on three elements of inherent risk: firm size, firm risk, and audit complexity. Alternate proxies for their measurement are possible and may yield different results.

Despite these limitations, this study makes several important contributions. Firstly, it provides a counterpoint to the Ittonen et al. (2010) study by demonstrating contradictory results. This establishes the need for more intensive study to better understand how such divergent findings are possible. Secondly, this study proposes a conceptual model that integrates the two opposing approaches of explaining audit committee effectiveness on audit fees and has used this model to explain the impact of female representation on the audit committee. By incorporating both supply-side and demand-side approaches, we provide a parsimonious yet inclusive framework for future research into these contradictory findings. Thirdly, we provide empirical evidence to support the proposition that female representation is a significant factor in impacting audit fees but that the impact is different depending on situational factors inherent to the firm and the audit. Each of these contributions has important ramifications not only for the academic understanding of this phenomenon but also for practitioners and policymakers. Given the differential impact of women in governance roles, there may be situations which do not benefit from their influence. However, there may be situations in which female presence is not only important but crucial to effective governance. 


\section{References}

Abbott, L. J., S. Parker, and G. F. Peters, 2004, Audit committee characteristics and restatements, Auditing: A Journal of Practice and Theory 23(1), 69-87.

Abbott, L. J., S. Parker, G. F. Peters, and K. Raghunandan, 2003, The association between audit committee characteristics and audit fees, Auditing: A Journal of Practice and Theory 22(2), 17-32.

Abbott, L. J., S. Parker and T. J. Presley, 2012, Female board presence and the likelihood of financial restatement, Accounting Horizons 26(4), 607-629.

Adams, R. B., and D. Ferreira, 2009, Women in the boardroom and their impact on governance and performance, Journal of Financial Economics 94(2), 291-309.

Aldamen, H., 2010, The association between corporate governance, risk assessment and debt contracting (Unpublished doctoral thesis), Bond University, Gold Coast, Australia.

Arun, T. G., Y. E. Almahrog, and S. A. Aribi, 2015, Female directors and earnings management: Evidence from UK companies, International Review of Financial Analysis 39, 137-146.

ASX Corporate Governance Council, 2010, Corporate governance principles and recommendations with 2010 amendments $2^{\text {nd }}$ ed, Australian Securities Exchange, Sydney.

Australian Institute of Company Directors, 2011, Audit committee charter. Available at: www.companydirectors.com.au.

Barber, B.M., and T. Odean, 2001, Boys will be boys: Gender, overconfidence, and common stock investment, Quarterly Journal of Economics 116(1), 261-292.

Bart, C., and G. McQueen, 2013, Why women make better directors, International Journal of Business Governance and Ethics 8(1), 93-99. 
Barua, A., L. F. Davidson, D. V. Rama, and S. Thiruvadi, 2010, CFO gender and accruals Quality, Accounting Horizons 24(1), 25-39.

Beasley, M. S., J. V. Carcello, D. R. Hermanson, and T. L. Neal, 2009, The audit committee oversight process, Contemporary Accounting Research 26(1), 65-122.

Bliss, M. A., 2011, Does CEO duality constrain board independence? Some evidence from audit pricing, Accounting and Finance 51(2), 361-380.

Boo, E. F., and D. Sharma, 2008, Effect of regulatory oversight on the association between internal governance characteristics and audit fees, Accounting and Finance 48(1), 51-71.

Burgess, Z., and P. Tharenou, 2002, Women board directors: Characteristics of the few. Journal of Business Ethics 37(1), 39-49.

Byrnes, J.P., D.C. Miller, and W.D. Schaefer, 1999, Gender differences in risk taking: A metaanalysis, Psychological Bulletin 125(3), 367-383.

Cahan, S., and J. Sun, 2014, The Effect of Audit Experience on Audit Fees and Audit Quality, Journal of Accounting, Auditing and Finance 30(1), 78-100.

Campbell, K., and A. Mínguez-Vera, 2008, Gender diversity in the boardroom and firm financial performance, Journal of Business Ethics 83(3), 435-451.

Campbell, K., and A. Mínguez-Vera, 2010, Female board appointments and firm valuation: Short and long-term effects, Journal of Management and Governance 14(1), 37-59.

Carcello, J. V., D. R. Hermanson, T. L. Neal, and R. A. Riley, 2002, Board characteristics and audit fees, Contemporary Accounting Research 19(3), 365-384.

Carter, D. A., F. D'Souza, B. J. Simkins, and W. G. Simpson, 2010, The gender and ethnic diversity of US boards and board committees and firm financial performance, Corporate Governance: An International Review 18(5), 396-414. 
Carter, D. A., B. J. Simkins, and W. G. Simpson, 2003, Corporate governance, board diversity, and firm value, Financial Review 38(1), 33-53.

Chan, A. M. Y., G. Liu, and J. Sun, 2013, Independent audit committee members’ board tenure and audit fees, Accounting and Finance 53(4), 1129-1147.

Chapple, L., and J. E. Humphrey, 2014, Does board gender diversity have a financial impact? Evidence using stock portfolio performance, Journal of Business Ethics 122(4), 709-723.

Chapple, L., and T. P. Truong, 2015, Continuous disclosure compliance: does corporate governance matter?, Accounting and Finance 55(4), 965-988.

Charness, G., and U. Gneezy, 2012, Strong evidence for gender differences in risk taking, Journal of Economic Behavior and Organization 83(1), 50-58.

Cohen, J. R., G. Krishnamoorthy, and A. M. Wright, 2008, Form versus substance: The implications for auditing practice and research of alternative perspectives on corporate governance, Auditing: A Journal of Practice and Theory 27(2), 181-198.

Collier, P., and A. Gregory, 1996, Audit committee effectiveness and the audit fee, European Accounting Review 5(2), 177-198.

Connelly, B. L., R. E. Hoskisson, L. Tihanyi, and S. T. Certo, 2010, Ownership as a form of corporate governance, Journal of Management Studies 47(8), 1561-1589.

Daily, M.D., D.R. Dalton, and A.A. Cannella, 2003, Corporate governance: Decades of dialogue and data, Academy of Management Review 28(3), 371-382.

Davies, E. W., 2011, Women on boards February 2011. UK Department for Business, Innovation \& Skills, Available at https://www.gov.uk/government/uploads/system/uploads/ attachment_data/file/31480/11-745-women-on-boards.pdf. 
De Lacy, G., 2005, How to review and assess the value of board subcommittees. Australian Institute of Company Directors.

DiMaggio, P. J., and W. W. Powell, 1983, The iron cage revisited: Institutional isomorphism and collective rationality in organizational fields, American Sociological Review 48(2), 147160.

Dunn, P., 2012, The role of gender and human capital on the appointment of new corporate directors to boardroom committees: Canadian evidence, International Business Research 5(5), $16-25$.

Dwyer, P.D., J.H. Gilkeson, and J.A. List, 2002, Gender differences in revealed risk taking: evidence from mutual fund investors, Economics Letters 76 (1), 151-158.

Erhardt, N. L., J. D. Werbel, and C. B. Shrader, 2003, Board of director diversity and firm financial performance, Corporate Governance: An International Review 11(2), 102-111.

Financial Reporting Council, 2014, The UK corporate governance code, London.

Fondas, N., and Sassalos, 2000, A different voice in the boardroom : How the presence of women directors affects board influence over management, Global Focus 12(2), 13-22.

Francis, J. R., and D. T. Simon, 1987, A test of audit pricing in the small-client segment of the U.S. audit market, The Accounting Review 62(1), 145-157.

Goodwin-Stewart, J., and P. Kent, 2006, Relation between external audit fees, audit committee characteristics and internal audit, Accounting and Finance 46(3), 387-404.

Griffin, P. A., D. H. Lont, and Y. Sun, 2008, Corporate governance and audit fees: Evidence of countervailing relations, Journal of Contemporary Accounting and Economics 4(1), 18-49.

Gul, F. A., M. Hutchinson, and K. M. Lai, 2013, Gender-diverse boards and properties of analyst earnings forecasts, Accounting Horizons 27(3), 511-538. 
Gul, F. A., B. Srinidhi, and J. S. Tsui, 2008, Board diversity and the demand for higher audit effort, Working Paper SSRN 1359450. Available at: http://dx.doi.org/10.2139/ssrn.1359450. Hallahan, T.A., R.W. Faff, and M.D. Mckenzie, 2004, An empirical investigation of personal financial risk tolerance, Financial Services Review 13(1), 57-78.

Hay, D., W. R. Knechel, and H. Ling, 2008, Evidence on the impact of internal control and corporate governance on audit fees, International Journal of Auditing 12(1), 9-24.

Ho, S.S., A.Y. Li, K. Tam, and F. Zhang, 2015, CEO gender, ethical leadership, and accounting conservatism, Journal of Business Ethics 127(2), 351-370.

Hutchinson, M., J. Mack, and K. Plastow, 2015, Who selects the 'right'directors? An examination of the association between board selection, gender diversity and outcomes, Accounting and Finance 55(4), 1071-1103.

Ittonen, K., J. Miettinen, and S. Vähämaa, 2010, Does female representation on audit committees affect audit fees?, Quarterly Journal of Finance and Accounting 49(3/4), 113-139. Ittonen, K., and E. Peni, 2012, Auditor's gender and audit fees, International Journal of Auditing 16(1), 1-18.

Jianakoplos, N., and A. Bernasek, 1998, Are women more risk averse?, Economic Inquiry 36(4), 620-630.

Jiang, W., and M. Son, 2015, Do Audit Fees Reflect Risk Premiums for Control Risk? Journal of Accounting, Auditing and Finance 30(3), 318-340.

Joecks, J., K. Pull, and K. Vetter, 2013, Gender diversity in the boardroom and firm performance: What exactly constitutes a “critical mass”?, Journal of Business Ethics 118(1). $61-72$. 
Johnson, J.E.V., and P.L. Powell, 1994, Decision making, risk and gender: Are managers different?, British Journal of Management 5(2), 123-138.

Kalbers, L. P., and T. J. Fogarty, 1993, Audit committee effectiveness: An empirical investigation of the contribution of power, Auditing 12(1), 24.

Kamonjoh, E., 2014, Gender Diversity on Boards: A Review of Global Trends. Institute of Shareholder Services.

Kane, G. D., and U. Velury, 2004, The role of institutional ownership in the market for auditing services: An empirical investigation, Journal of Business Research 57(9), 976-983.

Kesner, I. F., 1988, Directors' characteristics and committee membership: An investigation of type, occupation, tenure, and gender, Academy of Management Journal 31(1), 66-84.

Klein, A., 2002, Audit committee, board of director characteristics, and earnings management, Journal of Accounting and Economics 33(3), 375-400.

Klein, A., 1998, Firm performance and board committee structure, Journal of Law and Economics 41(1), 275-303.

Konrad, A.M., V. Kramer and S. Erkut, 2008, Critical mass: The impact of three or more women on corporate boards, Organizational Dynamics 37(2), 145-164.

Krishnan, J., 2005, Audit committee quality and internal control: An empirical analysis, The Accounting Review 80(2), 649-675.

Krishnan, G., and G. Visvanathan, 2009, Do auditors price audit committee's expertise? The case of accounting versus nonaccounting financial experts, Journal of Accounting, Auditing and Finance 24(1), 115-144.

Larcker, D. F., and S. A. Richardson, 2004, Fees paid to audit firms, accrual choices, and corporate governance, Journal of Accounting Research 42(3), 625-658. 
Lee, H. Y., and V. Mande, 2005, The relationship of audit committee characteristics with endogenously determined audit and non-audit fees, Quarterly Journal of Business and Economics 44(3/4), 93-112.

Levin, I.P., S.L. Schneider, and G.J. Gaeth, 1998, All frames are not created equal: A typology and critical analysis of framing effects, Organizational Behavior and Human Decision Processes 76(2), 149-188.

Loukil, L., 2014, Audit committees and audit fees: An empirical study in large French listed companies, Journal of Accounting, Business and Management 21(2), 36-53.

Mano-Negrin, R., and Z. Sheaffer, 2004, Are women “cooler” than men during crises? Exploring gender differences in perceiving organisational crisis preparedness proneness, Women in Management Review 19(1/2), 109-122.

Meyer, J. W., and B. Rowan, 1977, Institutionalized organizations: Formal structure as myth and ceremony, American Journal of Sociology 83(2), 340-363.

Munro, L., and J. Stewart, 2011, External auditors' reliance on internal auditing: Further evidence, Managerial Auditing Journal 26(6), 464-481.

Ontario Securities Commission, 2013, OSC Staff Consultation Paper: 58-401-Disclosure Requirements Regarding Women on Boards and in Senior Management. Available at: https://www.osc.gov.on.ca/.

Peni, E., and S. Vähämaa, 2010, Female executives and earnings management, Managerial Finance 36(7), 629-645.

Post, C., and K. Byron, 2015, Women on boards and firm financial performance: A metaanalysis, Academy of Management Journal 58(5), 1546-1571. 
Powell, M., and D. Ansic, 1997, Gender differences in risk behaviour in financial decisionmaking: An experimental analysis, Journal of Economic Psychology 18 (6), 605-628.

Robinson, G., and K. Dechant, 1997, Building a business case for diversity, Academy of Management Executive, 11(3), 21-31.

Rose, C., 2007, Does female board representation influence firm performance? The Danish evidence, Corporate Governance: An International Review 15(2), 404-413.

Schmitt, D.P., A. Realo, M. Voracek and J. Allik, 2008, Why can’t a man be more like a woman? Sex differences in Big Five personality traits across 55 cultures, Journal of Personality and Social Psychology 94(1), 168-182.

Schubert, R., 2006, Analyzing and managing risks - on the importance of gender differences in risk attitudes, Managerial Finance 32(9), 706-715.

Simon, D.T., and J.R. Francis, 1988, The effects of auditor change on audit fees: Tests of price cutting and price recovery, The Accounting Review 64(2), 255-269.

Simunic, D. A., 1980, The pricing of audit services: Theory and evidence, Journal of Accounting Research 18(1), 161-190.

Srinidhi, B., F. A. Gul, and J. Tsui, 2011, Female directors and earnings quality, Contemporary Accounting Research 28(5), 1610-1644.

Stewart, J., and L. Munro, 2007, The impact of audit committee existence and audit committee meeting frequency on the external audit: Perceptions of Australian auditors, International Journal of Auditing 11(1), 51-69.

Sultana, N., and A. Rahman, Audit Committee Gender Diversity and Audit Fees, Paper presented at the 2016 AFAANZ Conference, Gold Coast. 
Sun, J., G. Liu, and G. Lan, 2011, Does female directorship on independent audit committees constrain earnings management?, Journal of Business Ethics 99(3), 369-382.

Thiruvadi, S., and H. W. Huang, 2011, Audit committee gender differences and earnings management, Gender in Management: An International Journal 26(7), 483-498.

Thiruvadi, S., 2012, Gender differences and audit committee diligence, Gender in Management: An International Journal 27(6), 366-379.

Thomas, D. A., and R. J. Ely, 1996, Making differences matter: A new paradigm for managing diversity, Harvard Business Review 74(5), 79-90.

Turley, S., and M. Zaman, 2007, Audit committee effectiveness: Informal processes and behavioural effects, Accounting, Auditing and Accountability Journal 20(5), 765-788.

Vafeas, N., and J. F. Waegelein, 2007, The association between audit committees, compensation incentives, and corporate audit fees, Review of Quantitative Finance and Accounting 28(3), 241-255.

Virtanen, A., 2012, Women on the boards of listed companies: Evidence from Finland, Journal of Management and Governance 16(4), 571-593.

Watson, J., and M. McNaughton, 2007, Gender differences in risk aversion and expected retirement benefits, Financial Analysts Journal 63(4), 52-62.

Wood, W., D. Polek, and C. Aiken, 1985, Sex differences in group task performance, Journal of Personality and Social Psychology 48(1), 63-71.

Xie, B., W. N. Davidson, and P. J. DaDalt, 2003, Earnings management and corporate governance: The role of the board and the audit committee, Journal of Corporate Finance 9(3), 295-316. 
Zaman, M., M. Hudaib, and R. Haniffa, 2011, Corporate governance quality, audit fees and non-audit services fees, Journal of Business Finance and Accounting 38(1-2), 165-197. 
Table 1: Descriptive Statistics

\begin{tabular}{|c|c|c|c|c|c|c|}
\hline & $\mathbf{N}$ & Mean & Median & $\begin{array}{c}\text { Std. } \\
\text { Deviation }\end{array}$ & Minimum & Maximum \\
\hline \multicolumn{7}{|c|}{ Panel A: All Companies } \\
\hline AUD_FEES & 624 & 5.031 & 4.941 & 0.514 & 2.732 & 7.158 \\
\hline FEM_CODE & 624 & 0.154 & N.A. & N.A. & N.A. & N.A. \\
\hline$A C \_I N D P$ & 624 & 0.586 & 0.667 & 0.392 & 0.000 & 1.000 \\
\hline$A C \_E X P$ & 624 & 0.470 & 0.500 & 0.351 & 0.000 & 1.000 \\
\hline$A C \_E D U$ & 624 & 0.259 & 0.250 & 0.282 & 0.000 & 1.000 \\
\hline SIZE & 624 & 7.816 & 7.722 & 0.974 & 4.263 & 11.071 \\
\hline$L E V$ & 624 & 0.400 & 0.267 & 0.906 & 0.007 & 10.000 \\
\hline INVREC & 624 & 0.179 & 0.086 & 0.489 & 0.000 & 11.462 \\
\hline BIG4 & 624 & 0.494 & N.A. & N.A. & N.A. & N.A. \\
\hline$R O A$ & 624 & -0.292 & -0.030 & 1.899 & -35.718 & 0.969 \\
\hline$C R$ & 624 & 6.689 & 2.215 & 13.968 & 0.000 & 226.060 \\
\hline \multicolumn{7}{|c|}{ Panel B: Female Representation on Audit Committees } \\
\hline AUD_FEES & 96 & 5.439 & 5.412 & 0.615 & 4.228 & 7.158 \\
\hline AC_INDP & 96 & 0.618 & 0.667 & 0.387 & 0.000 & 1.000 \\
\hline$A C \_E X P$ & 96 & 0.524 & 0.500 & 0.323 & 0.000 & 1.000 \\
\hline$A C \_E D U$ & 96 & 0.241 & 0.200 & 0.273 & 0.000 & 1.000 \\
\hline SIZE & 96 & 8.510 & 8.526 & 1.077 & 6.065 & 11.071 \\
\hline$L E V$ & 96 & 0.352 & 0.368 & 0.228 & 0.009 & 0.899 \\
\hline INVREC & 96 & 0.291 & 0.102 & 1.166 & 0.000 & 11.462 \\
\hline BIG4 & 96 & 0.720 & N.A. & N.A. & N.A. & N.A. \\
\hline$R O A$ & 96 & -0.006 & 0.054 & 0.222 & -1.196 & 0.578 \\
\hline$C R$ & 96 & 4.947 & 1.790 & 7.842 & 0.160 & 49.140 \\
\hline
\end{tabular}

Notes: $A U D \_F E E S=$ Natural $\log$ of audit fees, FEM_CODE $=1$ if one audit committee member is female and zero otherwise, $A C_{-} I N D P=$ Proportion of audit committee members that are independent and nonexecutive, $A C \_E X P=$ Proportion of audit committee members that have board experience, $A C \_E D U=$ Proportion of audit committee members with a finance or accounting degree (or have CPA, CMA or CFA), SIZE = Natural log of total assets, $L E V=$ Total debt to total assets, $I N V R E C=$ Total inventory and receivables divided by total assets, BIG4 $=$ One if the auditor is a Big Four and zero otherwise, $R O A=$ Earnings before interest and tax divided by total assets, $C R=$ Total current assets divided by total current liabilities. 
Table 2: Demographics of Audit Committees with Female Members

\begin{tabular}{|c|c|c|c|c|}
\hline & & $\begin{array}{c}\text { Female } \\
\text { Members }\end{array}$ & $\begin{array}{c}\text { Number of } \\
\text { Firms }\end{array}$ & $\%$ of Females \\
\hline \multirow[t]{4}{*}{ Committee Composition } & One Female & 80 & 96 & $83 \%$ \\
\hline & Two Females & 13 & 96 & $14 \%$ \\
\hline & Three Females & 2 & 96 & $2 \%$ \\
\hline & Four Females & 1 & 96 & $1 \%$ \\
\hline \multirow[t]{6}{*}{ Situational Factors } & Large Size & 69 & 312 & $22 \%$ \\
\hline & Small Size & 27 & 312 & $9 \%$ \\
\hline & High Risk & 59 & 312 & $19 \%$ \\
\hline & Low Risk & 37 & 312 & $12 \%$ \\
\hline & High Complexity & 53 & 312 & $17 \%$ \\
\hline & Low Complexity & 43 & 312 & $14 \%$ \\
\hline \multirow[t]{9}{*}{ Industry } & Energy & 11 & 92 & $12 \%$ \\
\hline & Materials & 20 & 224 & $9 \%$ \\
\hline & Industrial & 14 & 97 & $14 \%$ \\
\hline & Consumer Discretionary & 19 & 71 & $27 \%$ \\
\hline & Consumer Staples & 5 & 16 & $31 \%$ \\
\hline & Health Care & 13 & 52 & $25 \%$ \\
\hline & Information Technology & 4 & 40 & $10 \%$ \\
\hline & Telecom & 3 & 14 & $21 \%$ \\
\hline & Utilities & 7 & 18 & $39 \%$ \\
\hline
\end{tabular}


Table 3: Brown-Forsythe ANOVA for Variables in the Presence of Female Audit Committee Members

\begin{tabular}{|c|c|c|c|c|}
\hline \multicolumn{5}{|c|}{ FEM_CODE } \\
\hline \multirow{2}{*}{ Variable } & \multirow{2}{*}{ Factor } & \multirow{2}{*}{ Mean } & \multirow{2}{*}{$\begin{array}{c}\text { Std. } \\
\text { Deviation }\end{array}$} & ANOVA \\
\hline & & & & $F$ \\
\hline \multirow{3}{*}{ AUD_FEES } & No female & 4.957 & 0.456 & \multirow{3}{*}{$53.457 * * *$} \\
\hline & Female & 5.439 & 0.615 & \\
\hline & All & 5.031 & 0.514 & \\
\hline \multirow{3}{*}{$A C \_I N D P$} & No female & 0.581 & 0.394 & \multirow{3}{*}{0.765} \\
\hline & Female & 0.618 & 0.387 & \\
\hline & All & 0.586 & 0.392 & \\
\hline \multirow{3}{*}{$A C \_E X P$} & No female & 0.460 & 0.355 & \multirow{3}{*}{3.151} \\
\hline & Female & 0.524 & 0.323 & \\
\hline & All & 0.470 & 0.351 & \\
\hline \multirow{3}{*}{$A C \_E D U$} & No female & 0.263 & 0.284 & \multirow{3}{*}{0.496} \\
\hline & Female & 0.241 & 0.273 & \\
\hline & All & 0.259 & 0.282 & \\
\hline \multirow{3}{*}{ SIZE } & No female & 7.689 & 0.899 & \multirow{3}{*}{ 49.485*** } \\
\hline & Female & 8.510 & 1.077 & \\
\hline & All & 7.816 & 0.974 & \\
\hline \multirow{3}{*}{$L E V$} & No female & 0.409 & 0.980 & \multirow{3}{*}{1.358} \\
\hline & Female & 0.352 & 0.228 & \\
\hline & All & 0.400 & 0.906 & \\
\hline \multirow{3}{*}{ INVREC } & No female & 0.158 & 0.188 & \multirow{3}{*}{1.238} \\
\hline & Female & 0.291 & 1.166 & \\
\hline & All & 0.179 & 0.489 & \\
\hline \multirow{3}{*}{ BIG4 } & No female & 0.453 & 0.498 & \multirow{3}{*}{$27.255^{* * *}$} \\
\hline & Female & 0.719 & 0.452 & \\
\hline & All & 0.494 & 0.500 & \\
\hline \multirow{3}{*}{$R O A$} & No female & -0.344 & 2.059 & \multirow{3}{*}{$13.338^{* * *}$} \\
\hline & Female & -0.006 & 0.222 & \\
\hline & All & -0.292 & 1.899 & \\
\hline \multirow{3}{*}{$C R$} & No female & 7.006 & 14.795 & \multirow{3}{*}{$4.019 * *$} \\
\hline & Female & 4.947 & 7.842 & \\
\hline & All & 6.689 & 13.968 & \\
\hline
\end{tabular}

Notes:

***, **, * Significant at 1\%, 5\%, 10\%, two-tailed respectively.

This table presents Brown-Forsythe ANOVA due to the unequal groups of female and non-female audit committee members (96 with females and 528 with no females). Additionally, this test is used due to the lack of homogeneity of variances between the groups of female and non-female audit committee members. Refer to Table 1 for definitions of variables. 
Table 4: ANOVA for Variables for different sized companies, level of risk and complexity

\begin{tabular}{|c|c|c|c|c|}
\hline \multicolumn{5}{|c|}{ Firm Size } \\
\hline \multirow{2}{*}{ Variable } & \multirow{2}{*}{ Factor } & \multirow{2}{*}{ Mean } & \multirow{2}{*}{$\begin{array}{c}\text { Std. } \\
\text { Deviation }\end{array}$} & ANOVA \\
\hline & & & & $F$ \\
\hline \multirow{3}{*}{ AUD_FEES } & Small & 4.712 & 0.297 & \\
\hline & Large & 5.350 & 0.486 & $392.02 * * *$ \\
\hline & All & 5.031 & 0.514 & \\
\hline \multirow{3}{*}{ FEM_CODE } & Small & 0.087 & 0.282 & \\
\hline & Large & 0.221 & 0.416 & $22.427 * * *$ \\
\hline & All & 0.154 & 0.361 & \\
\hline \multirow{3}{*}{ AC_INDP } & Small & 0.515 & 0.398 & \\
\hline & Large & 0.658 & 0.374 & $21.547 * * *$ \\
\hline & All & 0.586 & 0.392 & \\
\hline \multirow{3}{*}{$A C \_E X P$} & Small & 0.451 & 0.359 & \\
\hline & Large & 0.489 & 0.342 & 1.862 \\
\hline & All & 0.470 & 0.351 & \\
\hline \multirow{3}{*}{$A C \_E D U$} & Small & 0.248 & 0.294 & \\
\hline & Large & 0.270 & 0.270 & 0.952 \\
\hline & All & 0.259 & 0.282 & \\
\hline \multicolumn{5}{|l|}{ SIZE } \\
\hline \multirow{3}{*}{$L E V$} & Small & 0.423 & 1.260 & \\
\hline & Large & 0.377 & 0.240 & 0.408 \\
\hline & All & 0.400 & 0.906 & \\
\hline \multirow{3}{*}{ INVREC } & Small & 0.184 & 0.672 & \\
\hline & Large & 0.173 & 0.168 & 0.084 \\
\hline & All & 0.179 & 0.489 & \\
\hline
\end{tabular}

\begin{tabular}{|c|c|c|c|c|}
\hline \multicolumn{5}{|c|}{ Risk } \\
\hline \multirow{2}{*}{ Variable } & \multirow{2}{*}{ Factor } & \multirow{2}{*}{ Mean } & \multirow{2}{*}{$\begin{array}{c}\text { Std. } \\
\text { Deviation }\end{array}$} & ANOVA \\
\hline & & & & $F$ \\
\hline \multirow{3}{*}{ AUD_FEES } & Low & 4.802 & 0.378 & \\
\hline & High & 5.260 & 0.530 & $154.73^{* * *}$ \\
\hline & All & 5.031 & 0.514 & \\
\hline \multirow{3}{*}{ FEM_CODE } & Low & 0.119 & 0.324 & \\
\hline & High & 0.189 & 0.392 & $5.996 * *$ \\
\hline & All & 0.154 & 0.361 & \\
\hline \multirow{3}{*}{$A C \_I N D P$} & Low & 0.540 & 0.396 & \\
\hline & High & 0.633 & 0.384 & $\mathbf{8 . 8 8 0} * * *$ \\
\hline & All & 0.586 & 0.392 & \\
\hline \multirow{3}{*}{ AC_EXP } & Low & 0.463 & 0.357 & \\
\hline & High & 0.477 & 0.344 & 0.269 \\
\hline & All & 0.470 & 0.351 & \\
\hline \multirow{3}{*}{$A C \_E D U$} & Low & 0.227 & 0.265 & \\
\hline & High & 0.291 & 0.295 & $8.022 * *$ \\
\hline & All & 0.259 & 0.282 & \\
\hline \multirow{3}{*}{ SIZE } & Low & 7.499 & 0.736 & \\
\hline & High & 8.132 & 1.076 & $73.489 * * *$ \\
\hline & All & 7.816 & 0.974 & \\
\hline \multicolumn{5}{|l|}{ LEV } \\
\hline \multirow{3}{*}{ INVREC } & Low & 0.120 & 0.657 & \\
\hline & High & 0.237 & 0.202 & $9.020 * * *$ \\
\hline & All & 0.179 & 0.489 & \\
\hline
\end{tabular}

\begin{tabular}{|c|c|c|c|c|}
\hline \multicolumn{5}{|c|}{ INVREC } \\
\hline \multirow{2}{*}{ Variable } & \multirow{2}{*}{ Factor } & \multirow{2}{*}{ Mean } & \multirow{2}{*}{$\begin{array}{c}\text { Std. } \\
\text { Deviation }\end{array}$} & ANOVA \\
\hline & & & & $F$ \\
\hline \multirow{3}{*}{ AUD_FEES } & Low & 4.857 & 0.460 & \\
\hline & High & 5.205 & 0.507 & $80.280 * * *$ \\
\hline & All & 5.031 & 0.514 & \\
\hline \multirow{3}{*}{ FEM_CODE } & Low & 0.138 & 0.345 & \\
\hline & High & 0.170 & 0.376 & 1.230 \\
\hline & All & 0.154 & 0.361 & \\
\hline \multirow{3}{*}{$A C \_I N D P$} & Low & 0.576 & 0.397 & \\
\hline & High & 0.596 & 0.388 & 0.412 \\
\hline & All & 0.586 & 0.392 & \\
\hline \multirow{3}{*}{$A C \_E X P$} & Low & 0.485 & 0.337 & \\
\hline & High & 0.455 & 0.364 & 1.127 \\
\hline & All & 0.470 & 0.351 & \\
\hline \multirow{3}{*}{$A C \_E D U$} & Low & 0.248 & 0.286 & \\
\hline & High & 0.27 & 0.278 & 0.986 \\
\hline & All & 0.259 & 0.282 & \\
\hline \multirow{3}{*}{ SIZE } & Low & 7.702 & 0.952 & \\
\hline & High & 7.929 & 0.984 & $8.630 * * *$ \\
\hline & All & 7.816 & 0.974 & \\
\hline \multirow{3}{*}{$L E V$} & Low & 0.284 & 0.805 & \\
\hline & High & 0.516 & 0.985 & $10.411^{* * *}$ \\
\hline & All & 0.400 & 0.906 & \\
\hline
\end{tabular}

41 


\begin{tabular}{|c|c|c|c|c|c|c|c|c|c|c|c|c|c|c|}
\hline \multirow{3}{*}{ BIG4 } & Small & 0.260 & 0.439 & \multirow{3}{*}{$174.48 * * *$} & \multirow{3}{*}{ BIG4 } & Low & 0.410 & 0.493 & \multirow{3}{*}{$16.398 * * *$} & \multirow{3}{*}{ BIG4 } & Low & 0.423 & 0.495 & \multirow{3}{*}{$12.624 * * *$} \\
\hline & Large & 0.728 & 0.446 & & & High & 0.570 & 0.495 & & & High & 0.564 & 0.497 & \\
\hline & All & 0.494 & 0.500 & & & All & 0.490 & 0.500 & & & All & 0.494 & 0.500 & \\
\hline \multirow{3}{*}{$R O A$} & Small & 0.622 & 2.644 & \multirow{3}{*}{$19.386 * * *$} & \multirow{3}{*}{$R O A$} & Low & -0.242 & 0.761 & \multirow{3}{*}{0.424} & \multirow{3}{*}{$R O A$} & Low & $0.260^{-}$ & 0.838 & \multirow{3}{*}{0.175} \\
\hline & Large & 0.038 & 0.138 & & & High & -0.341 & 2.577 & & & High & $0.324^{-}$ & 2.554 & \\
\hline & All & $0.292^{-}$ & 1.899 & & & All & -0.292 & 1.899 & & & All & $0.292^{-}$ & 1.899 & \\
\hline \multirow{3}{*}{$C R$} & Small & 8.292 & 12.026 & \multirow{3}{*}{$8.315 * * *$} & \multirow{3}{*}{$C R$} & Low & 11.781 & 18.36 & \multirow{3}{*}{$95.514 * * *$} & \multirow{3}{*}{$C R$} & Low & 10.17 & 18.370 & \multirow{3}{*}{$41.265 * * *$} \\
\hline & Large & 5.086 & 15.525 & & & High & 1.597 & 1.311 & & & High & 3.208 & 5.389 & \\
\hline & All & 6.689 & 13.968 & & & All & 6.689 & 13.968 & & & All & 6.689 & 13.968 & \\
\hline
\end{tabular}

Notes:

${ }^{* * *}, * *, *$ Significant at $1 \%, 5 \%, 10 \%$, two-tailed respectively.

This table presents ANOVA for the variables under three different situational factors. Refer to Table 1 for definitions of variables. 
Table 5: Correlation Analysis

\begin{tabular}{|c|c|c|c|c|c|c|c|c|c|c|}
\hline & FEM_CODE & $A C \_I N D P$ & $A C \_E X P$ & $A C \_E D U$ & SIZE & $L E V$ & INVREC & BIG4 & $R O A$ & $C R$ \\
\hline FEM_CODE & 1.000 & & & & & & & & & \\
\hline$A C \_I N D P$ & 0.035 & 1.000 & & & & & & & & \\
\hline$A C \_E X P$ & 0.066 & $-0.176 * * *$ & 1.000 & & & & & & & \\
\hline$A C \_E D U$ & -0.027 & -0.032 & $0.386 * * *$ & 1.000 & & & & & & \\
\hline SIZE & $0.304 * * *$ & $0.216 * * *$ & 0.045 & 0.036 & 1.000 & & & & & \\
\hline$L E V$ & -0.023 & -0.017 & 0.056 & 0.036 & $-0.147^{* * *}$ & 1.000 & & & & \\
\hline INVREC & $0.098 * *$ & 0.037 & 0.010 & 0.075 & -0.023 & 0.043 & 1.000 & & & \\
\hline BIG4 & $0.192 * * *$ & $0.157 * * *$ & 0.027 & -0.038 & $0.516 * * *$ & -0.008 & -0.016 & 1.000 & & \\
\hline$R O A$ & 0.064 & 0.030 & -0.030 & 0.022 & $0.335^{* * *}$ & $-0.603^{* * *}$ & -0.024 & $0.105^{* * *}$ & 1.000 & \\
\hline$C R$ & -0.053 & -0.021 & -0.030 & $-0.102 * *$ & $-0.124 * * *$ & $-0.155^{* * *}$ & 0.005 & $-0.098 * *$ & 0.010 & 1.000 \\
\hline
\end{tabular}

Notes: ${ }^{* * *, * *}$ Significant at $1 \%, 5 \%$, two-tailed respectively. Refer to Table 1 for definitions of variables. 
Table 6: The Relationship between Audit Fees and Female Directors on the Audit Committee

\begin{tabular}{|c|c|c|c|c|}
\hline Variables & Model 1 & Model 2 & Model 3 & Model 4 \\
\hline FEM_CODE & $\begin{array}{r}\mathbf{0 . 0 9 4} * * * \\
(3.968)\end{array}$ & $\begin{array}{r}\mathbf{0 . 0 7 4} * * * \\
(3.215)\end{array}$ & & \\
\hline FEM_NUM & & & $\begin{array}{r}\mathbf{0 . 0 8 7} * * * \\
(3.696)\end{array}$ & $\begin{array}{r}\text { 0.063*** } \\
(2.761)\end{array}$ \\
\hline AC_INDP & $\begin{array}{l}\text { 0.043* } \\
(1.862)\end{array}$ & $\begin{array}{r}0.035 \\
(1.550)\end{array}$ & $\begin{array}{c}\text { 0.044* } \\
\text { (1.873) }\end{array}$ & $\begin{array}{r}0.035 \\
(1.551)\end{array}$ \\
\hline$A C \_E X P$ & $\begin{array}{r}0.001 \\
(0.018)\end{array}$ & $\begin{array}{r}-0.013 \\
-(0.547)\end{array}$ & $\begin{array}{r}-0.001 \\
-(0.034)\end{array}$ & $\begin{array}{r}-0.013 \\
-(0.561)\end{array}$ \\
\hline$A C \_E D U$ & $\begin{array}{r}-0.023 \\
-(0.946)\end{array}$ & $\begin{array}{r}-0.017 \\
-(0.704)\end{array}$ & $\begin{array}{r}-0.025 \\
-(1.034)\end{array}$ & $\begin{array}{r}-0.018 \\
-(0.777)\end{array}$ \\
\hline SIZE & $\begin{array}{r}\mathbf{0 . 6 0 9} * * * \\
(20.987)\end{array}$ & $\begin{array}{r}\text { 0.621*** } \\
(21.792)\end{array}$ & $\begin{array}{r}\mathbf{0 . 6 1 5 * * *} \\
(21.401)\end{array}$ & $\begin{array}{r}\mathbf{0 . 6 2 7 * * *} \\
(22.202)\end{array}$ \\
\hline$L E V$ & $\begin{array}{r}\mathbf{0 . 1 6 2} * * * \\
(5.683)\end{array}$ & $\begin{array}{r}\mathbf{0 . 1 2 7 * * *} \\
(4.534)\end{array}$ & $\begin{array}{r}\mathbf{0 . 1 6 2 * * *} \\
(5.680)\end{array}$ & $\begin{array}{r}\mathbf{0 . 1 2 7 * * *} \\
(4.539)\end{array}$ \\
\hline INVREC & $\begin{array}{r}\mathbf{0 . 0 7 0} \text { *** } \\
(3.095)\end{array}$ & $\begin{array}{c}\text { 0.039* } \\
(1.756)\end{array}$ & $\begin{array}{r}\text { 0.072*** } \\
(3.193)\end{array}$ & $\begin{array}{c}\mathbf{0 . 0 4 1}^{*} \\
(1.854)\end{array}$ \\
\hline BIG4 & $\begin{array}{r}\mathbf{0 . 2 5 4 * * *} \\
(9.687)\end{array}$ & $\begin{array}{r}\text { 0.236*** } \\
(9.288)\end{array}$ & $\begin{array}{r}\mathbf{0 . 2 5 2 * * *} \\
(9.583)\end{array}$ & $\begin{array}{r}\mathbf{0 . 2 3 5 * * *} \\
(9.224)\end{array}$ \\
\hline$R O A$ & $\begin{array}{r}0.006 \\
(0.204)\end{array}$ & $\begin{array}{r}-0.014 \\
-(0.484)\end{array}$ & $\begin{array}{r}0.005 \\
(0.186)\end{array}$ & $\begin{array}{r}-0.014 \\
-(0.501)\end{array}$ \\
\hline$C R$ & $\begin{array}{r}-\mathbf{0 . 0 8 9} * * * \\
(-3.864)\end{array}$ & $\begin{array}{r}-\mathbf{0 . 0 4 8} * * \\
-(2.130)\end{array}$ & $\begin{array}{r}-\mathbf{0 . 0 8 8} * * * \\
(-3.865)\end{array}$ & $\begin{array}{r}-\mathbf{0 . 0 4 8 * *} \\
-(2.133)\end{array}$ \\
\hline Energy & & $\begin{array}{r}-\mathbf{0 . 1 7 6 * * *} \\
-(3.212)\end{array}$ & & $\begin{array}{r}-\mathbf{0 . 1 7 4 * * *} \\
-(3.177)\end{array}$ \\
\hline Materials & & $\begin{array}{r}-\mathbf{0 . 2 6 8} * * * \\
-(3.747)\end{array}$ & & $\begin{array}{r}-\mathbf{0 . 2 6 7 * * *} \\
-(3.726)\end{array}$ \\
\hline Industrial & & $\begin{array}{l}-\mathbf{0 . 0 9 1} \text { * } \\
-(1.651)\end{array}$ & & $\begin{array}{l}-\mathbf{0 . 0 9 4} * \\
-(1.690)\end{array}$ \\
\hline Consumer Discretionary & & $\begin{array}{r}-0.068 \\
-(1.370)\end{array}$ & & $\begin{array}{r}-0.066 \\
-(1.338)\end{array}$ \\
\hline Consumer Staples & & $\begin{array}{r}-0.028 \\
-(0.919)\end{array}$ & & $\begin{array}{r}-0.027 \\
-(0.888)\end{array}$ \\
\hline Health care & & $\begin{array}{r}-0.032 \\
-(0.713)\end{array}$ & & $\begin{array}{r}-0.032 \\
-(0.698)\end{array}$ \\
\hline Information Tech & & $\begin{array}{r}-0.18 \\
-(0.446)\end{array}$ & & $\begin{array}{r}-0.017 \\
-(0.419)\end{array}$ \\
\hline Utilities & & $\begin{array}{r}0.048 \\
-(1.504)\end{array}$ & & $\begin{array}{r}-0.047 \\
-(1.449)\end{array}$ \\
\hline Adjusted R ${ }^{2}$ & $\begin{array}{r}\mathbf{0 . 6 9 2} \\
624\end{array}$ & $\begin{array}{r}0.719 \\
624\end{array}$ & $\begin{array}{r}0.691 \\
624\end{array}$ & $\begin{array}{r}0.717 \\
624\end{array}$ \\
\hline
\end{tabular}

Notes:

${ }^{* * *, * *, *}$ Significant at $1 \%, 5 \%, 10 \%$, two-tailed respectively.

Model 1 presents regression results for the relationship between audit fees and female directors on the audit committee. Model 2 includes industry fixed effects. The t-values are given in parenthesis below each estimate. Variance inflation factors (VIF) does not suggest multicollinearity. Refer to Table 1 for definitions of variables. 
Table 7: The Relationship between Audit Fees and Female Directors on the Audit Committee for Different-Sized Companies

\begin{tabular}{|c|c|c|c|}
\hline \multirow[b]{2}{*}{ Variables } & \multicolumn{3}{|c|}{ Size } \\
\hline & Small & Large & Interaction \\
\hline FEM_CODE & $\begin{array}{r}0.056 \\
(1.160)\end{array}$ & $\begin{array}{r}0.228 * * * \\
(5.048)\end{array}$ & $\begin{array}{r}-\mathbf{0 . 6 9 9} * * * \\
-(3.925)\end{array}$ \\
\hline SIZE & & & $\begin{array}{r}\mathbf{0 . 5 6 6} \\
(18 * * * 458)\end{array}$ \\
\hline SIZE_INTR & & & $\begin{array}{r}\mathbf{0 . 7 9 7} * * * \\
(4.374)\end{array}$ \\
\hline$A C \_I N D P$ & $\begin{array}{r}0.043 \\
(0.885)\end{array}$ & $\begin{array}{l}\text { 0.079* } \\
(1.731)\end{array}$ & $\begin{array}{r}0.028 \\
(1.278)\end{array}$ \\
\hline$A C \_E X P$ & $\begin{array}{r}-0.046 \\
-(0.894)\end{array}$ & $\begin{array}{r}0.054 \\
(1.095)\end{array}$ & $\begin{array}{r}-0.009 \\
-(0.370)\end{array}$ \\
\hline$A C \_E D U$ & $\begin{array}{r}-0.019 \\
-(0.371)\end{array}$ & $\begin{array}{r}-0.020 \\
-(0.411)\end{array}$ & $\begin{array}{r}-0.021 \\
-(0.906)\end{array}$ \\
\hline$L E V$ & $\begin{array}{r}\mathbf{0 . 1 7 6 * * *} \\
(2.800)\end{array}$ & $\begin{array}{r}0.227^{* * *} \\
(4.460)\end{array}$ & $\begin{array}{r}\mathbf{0 . 1 2 0} * * * \\
(4.363)\end{array}$ \\
\hline INVREC & $\begin{array}{r}0.076 \\
(1.484)\end{array}$ & $\begin{array}{c}\text { 0.094* } \\
(1.810)\end{array}$ & $\begin{array}{r}\mathbf{0 . 0 5 2} * * \\
(2.335)\end{array}$ \\
\hline BIG4 & $\begin{array}{r}0.337 * * * \\
(6.937)\end{array}$ & $\begin{array}{r}\mathbf{0 . 4 0 9} * * * \\
(9.097)\end{array}$ & $\begin{array}{r}\mathbf{0 . 2 3 8} * * * \\
(9.539)\end{array}$ \\
\hline$R O A$ & $\begin{array}{r}0.190 * * * \\
(3.104)\end{array}$ & $\begin{array}{r}0.063 \\
(1.400)\end{array}$ & $\begin{array}{r}-0.002 \\
-(0.062)\end{array}$ \\
\hline$C R$ & $\begin{array}{r}-0.059 \\
-(1.159)\end{array}$ & $\begin{array}{r}-0.051 \\
-(1.112)\end{array}$ & $\begin{array}{c}-\mathbf{0 . 0 4 6} \\
-(2.065)\end{array}$ \\
\hline Energy & $\begin{array}{c}-\mathbf{0 . 2 7 0} * * \\
-(2.214)\end{array}$ & $\begin{array}{r}-0.151 \\
-(1.355)\end{array}$ & $\begin{array}{r}-\mathbf{0 . 1 4 4} * * * \\
-(2.642)\end{array}$ \\
\hline Materials & $\begin{array}{c}-\mathbf{0 . 3 7 8} * * \\
-(2.334)\end{array}$ & $\begin{array}{c}-0.297 * * \\
-(2.127)\end{array}$ & $\begin{array}{r}-\mathbf{0 . 2 2 4} * * * \\
(-3.153)\end{array}$ \\
\hline Industrial & $\begin{array}{r}-0.069 \\
-(0.682)\end{array}$ & $\begin{array}{l}-0.233^{*} \\
-(1.838)\end{array}$ & $\begin{array}{r}-0.055 \\
-(0.998)\end{array}$ \\
\hline Consumer Discretionary & $\begin{array}{r}0.043 \\
(0.437)\end{array}$ & $\begin{array}{c}-\mathbf{0 . 2 0 3} * \\
-(1.855)\end{array}$ & $\begin{array}{r}-0.038 \\
-(0.775)\end{array}$ \\
\hline Consumer Staples & $\begin{array}{r}-0.086 \\
-(1.547)\end{array}$ & $\begin{array}{r}-0.087 \\
-(1.203)\end{array}$ & $\begin{array}{r}-0.025 \\
-(0.825)\end{array}$ \\
\hline Health care & $\begin{array}{r}0.001 \\
(0.011)\end{array}$ & $\begin{array}{r}-0.129 \\
-(1.620)\end{array}$ & $\begin{array}{r}-0.006 \\
-(0.128)\end{array}$ \\
\hline Information Tech & $\begin{array}{r}0.009 \\
(0.084)\end{array}$ & $\begin{array}{c}-\mathbf{0 . 1 1 7} * \\
-(1.707)\end{array}$ & $\begin{array}{r}0.001 \\
(0.035)\end{array}$ \\
\hline Utilities & $\begin{array}{c}-\mathbf{0 . 1 3 4} * * \\
-(1.976)\end{array}$ & $\begin{array}{r}-0.048 \\
-(0.707)\end{array}$ & $\begin{array}{r}-0.046 \\
-(1.465)\end{array}$ \\
\hline $\mathrm{N}$ & 312 & 312 & 624 \\
\hline Adj. $R^{2}$ & 0.326 & 0.435 & 0.727 \\
\hline
\end{tabular}

Notes:

$* * *, * *$, and $*$ denote significant at the $1 \%, 5 \%$ and $10 \%$ levels.

The t-values are given in parenthesis below each estimate. Refer to Table 1 for definitions of variables. 
Table 8: The Relationship between Audit Fees and Female Directors on the Audit Committee in the presence of Company Risk

\begin{tabular}{|c|c|c|c|}
\hline \multirow[b]{2}{*}{ Variables } & \multicolumn{3}{|c|}{ Risk } \\
\hline & Low Risk & High Risk & Interaction \\
\hline \multirow[t]{2}{*}{ FEM_CODE } & $0.076 * *$ & $0.072 * *$ & -0.001 \\
\hline & (1.993) & $(2.026)$ & $-(0.012)$ \\
\hline \multirow[t]{2}{*}{$L E V$} & & & $0.122 * * *$ \\
\hline & & & (4.364) \\
\hline \multirow[t]{2}{*}{ LEV_INTR } & & & $0.098 * *$ \\
\hline & & & $(2.426)$ \\
\hline \multirow[t]{2}{*}{$A C \_I N D P$} & 0.034 & 0.017 & 0.034 \\
\hline & (0.898) & $(0.515)$ & (1.535) \\
\hline \multirow[t]{2}{*}{$A C \_E X P$} & -0.015 & 0.005 & -0.012 \\
\hline & $-(0.372)$ & (0.135) & $-(0.499)$ \\
\hline \multirow[t]{2}{*}{$A C \_E D U$} & $-0.067^{*}$ & -0.010 & -0.020 \\
\hline & $-(1.711)$ & $-(0.272)$ & $-(0.863)$ \\
\hline \multirow[t]{2}{*}{ SIZE } & $0.548 * * *$ & $0.646^{* * *}$ & $0.606^{* * *}$ \\
\hline & $(12.762)$ & (13.903) & $(20.932)$ \\
\hline \multirow[t]{2}{*}{ INVREC } & 0.053 & $0.107 * * *$ & $0.048 * *$ \\
\hline & (1.295) & (3.040) & (2.113) \\
\hline \multirow[t]{2}{*}{ BIG4 } & $0.280 * * *$ & $0.282 * * *$ & $0.237 * * *$ \\
\hline & (6.825) & (7.232) & (9.379) \\
\hline \multirow[t]{2}{*}{$R O A$} & $-0.108 * * *$ & $-0.094^{* * *}$ & -0.013 \\
\hline & $-(2.639)$ & $-(2.699)$ & $-(0.447)$ \\
\hline \multirow[t]{2}{*}{$C R$} & -0.059 & -0.011 & $-0.045^{* *}$ \\
\hline & $-(1.575)$ & $-(0.352)$ & $-(2.014)$ \\
\hline \multirow[t]{2}{*}{ Energy } & 0.513* & $-0.118 * *$ & $-0.163^{* * *}$ \\
\hline & (1.948) & $-(2.131)$ & $-(2.972)$ \\
\hline \multirow[t]{2}{*}{ Materials } & $0.602 *$ & $-0.230 * * *$ & $-0.253^{* * *}$ \\
\hline & (1.838) & $-(3.285)$ & $(-3.542)$ \\
\hline \multirow[t]{2}{*}{ Industrial } & $0.310^{* *}$ & $-0.142^{*}$ & -0.085 \\
\hline & (2.046) & $-(1.945)$ & $-(1.534)$ \\
\hline \multirow[t]{2}{*}{ Consumer Discretionary } & $0.418 * * *$ & $-0.124^{*}$ & -0.064 \\
\hline & $(2.675)$ & $-(1.904)$ & $-(1.286)$ \\
\hline \multirow[t]{2}{*}{ Consumer Staples } & $0.137 *$ & -0.055 & -0.029 \\
\hline & (1.869) & $-(1.262)$ & $-(0.938)$ \\
\hline \multirow[t]{2}{*}{ Health care } & $0.515 * * *$ & -0.066 & -0.026 \\
\hline & (2.708) & $-(1.268)$ & $-(0.588)$ \\
\hline \multirow[t]{2}{*}{ Information Tech } & $0.421 * * *$ & -0.028 & -0.012 \\
\hline & (2.689) & $-(0.548)$ & $-(0.290)$ \\
\hline \multirow[t]{2}{*}{ Utilities } & 0.160 & -0.026 & $-0.056 *$ \\
\hline & $(1.623)$ & $-(0.585)$ & $-(1.740)$ \\
\hline $\mathrm{N}$ & 312 & 312 & 624 \\
\hline Adj. $R^{2}$ & 0.587 & 0.701 & 0.721 \\
\hline
\end{tabular}

Notes:

$* * *, * *$, and $*$ denote significant at the $1 \%, 5 \%$ and $10 \%$ levels.

The t-values are given in parenthesis below each estimate. Refer to Table 1 for definitions of variables. 
Table 9: The Relationship between Audit Fees and Female Directors on the Audit Committee in the presence of Audit Complexity

\begin{tabular}{|c|c|c|c|}
\hline \multirow[b]{2}{*}{ Variables } & \multicolumn{3}{|c|}{ Complexity } \\
\hline & Low INVREC & High INVREC & Interaction \\
\hline \multirow[t]{2}{*}{ FEM_CODE } & $0.086 * *$ & $0.057^{*}$ & $0.122 * * *$ \\
\hline & $(2.436)$ & (1.821) & (4.967) \\
\hline \multirow[t]{2}{*}{ INVREC } & & & $0.357 * * *$ \\
\hline & & & (5.220) \\
\hline \multirow[t]{2}{*}{ INVREC_INTR } & & & $-0.340 * * *$ \\
\hline & & & $-(4.905)$ \\
\hline \multirow[t]{2}{*}{$A C \_I N D P$} & $0.121 * * *$ & -0.013 & 0.033 \\
\hline & (3.381) & $-(0.463)$ & (1.489) \\
\hline \multirow[t]{2}{*}{$A C \_E X P$} & 0.015 & -0.032 & -0.005 \\
\hline & $(0.410)$ & $-(0.977)$ & $-(0.235)$ \\
\hline \multirow[t]{2}{*}{$A C \_E D U$} & -0.053 & 0.015 & -0.014 \\
\hline & $-(1.480)$ & $(0.467)$ & $-(0.622)$ \\
\hline \multirow[t]{2}{*}{ SIZE } & $0.553^{* * *}$ & $0.769 * * *$ & $0.627 * * *$ \\
\hline & (12.583) & (18.710) & (22.414) \\
\hline \multirow[t]{2}{*}{$L E V$} & $0.114 * * *$ & $0.181 * * *$ & $0.126 * * *$ \\
\hline & (3.244) & (3.808) & (4.582) \\
\hline \multirow[t]{2}{*}{ BIG4 } & $0.254 * * *$ & $0.196 * * *$ & $0.234 * * *$ \\
\hline & (6.639) & (5.786) & (9.386) \\
\hline \multirow[t]{2}{*}{$R O A$} & $-0.081 * *$ & 0.008 & -0.007 \\
\hline & $-(2.200)$ & $(0.169)$ & $-(0.232)$ \\
\hline \multirow[t]{2}{*}{$C R$} & -0.034 & -0.031 & -0.034 \\
\hline & $-(0.992)$ & $-(0.991)$ & $-(1.509)$ \\
\hline \multirow[t]{2}{*}{ Energy } & -0.192 & -0.069 & $-0.144 * * *$ \\
\hline & $-(1.101)$ & $-(1.455)$ & $-(2.667)$ \\
\hline \multirow[t]{2}{*}{ Materials } & -0.308 & $-0.129 * *$ & $-0.223 * * *$ \\
\hline & $-(1.468)$ & $-(2.032)$ & -(3.149) \\
\hline \multirow[t]{2}{*}{ Industrial } & -0.107 & -0.072 & $-0.099 *$ \\
\hline & $-(1.096)$ & $-(1.079)$ & $-(1.820)$ \\
\hline \multirow[t]{2}{*}{ Consumer Discretionary } & -0.047 & -0.053 & -0.075 \\
\hline & $-(0.436)$ & $-(0.910)$ & $-(1.531)$ \\
\hline \multirow[t]{2}{*}{ Consumer Staples } & 0.001 & -0.051 & -0.032 \\
\hline & $(0.025)$ & $-(1.247)$ & $-(1.046)$ \\
\hline \multirow[t]{2}{*}{ Health care } & -0.054 & 0.014 & -0.020 \\
\hline & $-(0.483)$ & $(0.274)$ & $-(0.457)$ \\
\hline \multirow[t]{2}{*}{ Information Tech } & -0.054 & 0.026 & -0.016 \\
\hline & $-(0.730)$ & $(0.517)$ & $-(0.393)$ \\
\hline \multirow[t]{2}{*}{ Utilities } & -0.002 & -0.030 & -0.027 \\
\hline & $-(0.025)$ & $-(0.954)$ & $-(0.837)$ \\
\hline $\mathrm{N}$ & 312 & 312 & 624 \\
\hline Adj. $R^{2}$ & 0.660 & 0.768 & 0.729 \\
\hline
\end{tabular}

Notes:

$* * *, * *$, and $*$ denote significant at the $1 \%, 5 \%$ and $10 \%$ levels.

The t-values are given in parenthesis below each estimate. Refer to Table 1 for definitions of variables. 
Figure 1. Unified Model of Supply-side and Demand-side Theories of Audit Committee Effectiveness

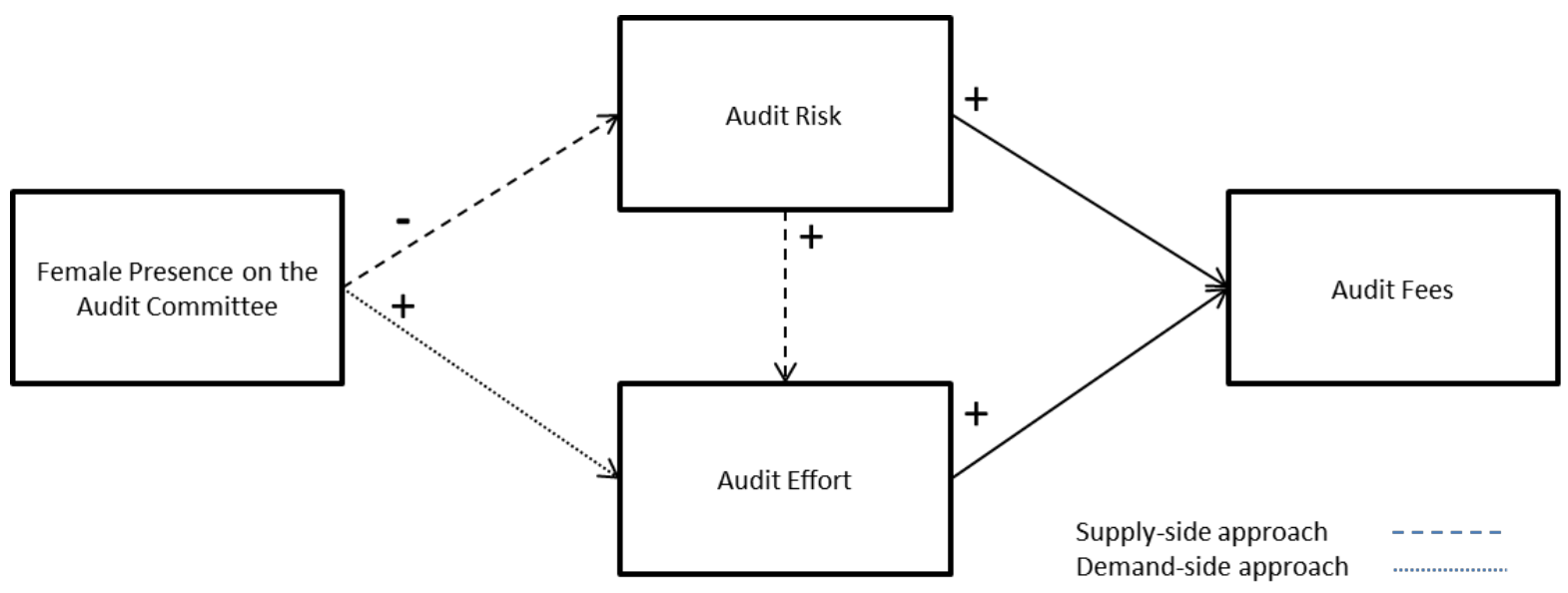


Figure 2. Interaction Effect of Female Representation on the Audit Committee with Firm Size in Determining Audit Fees

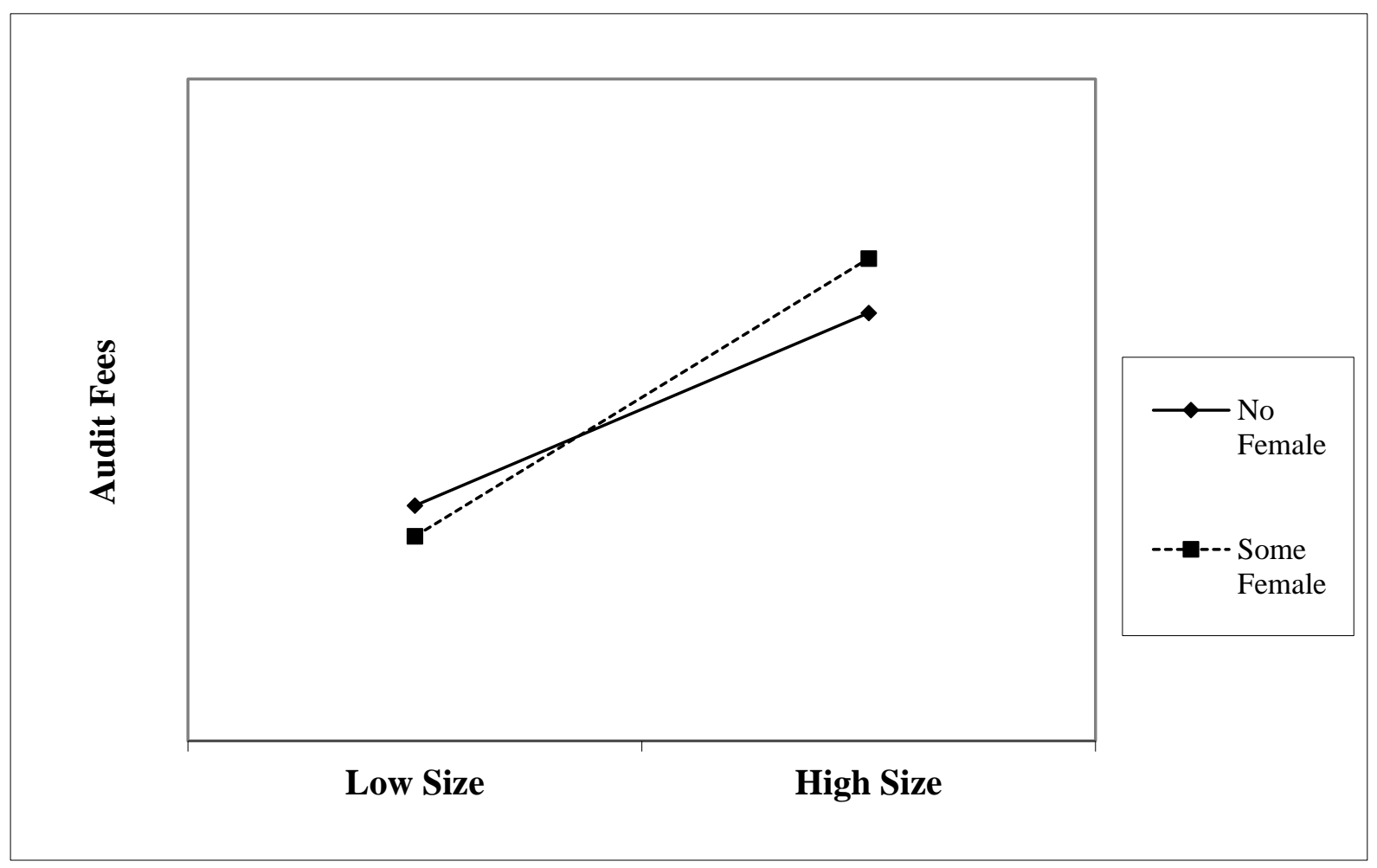


Figure 3. Interaction Effect of Female Representation on the Audit Committee with Audit Risk in Determining Audit Fees

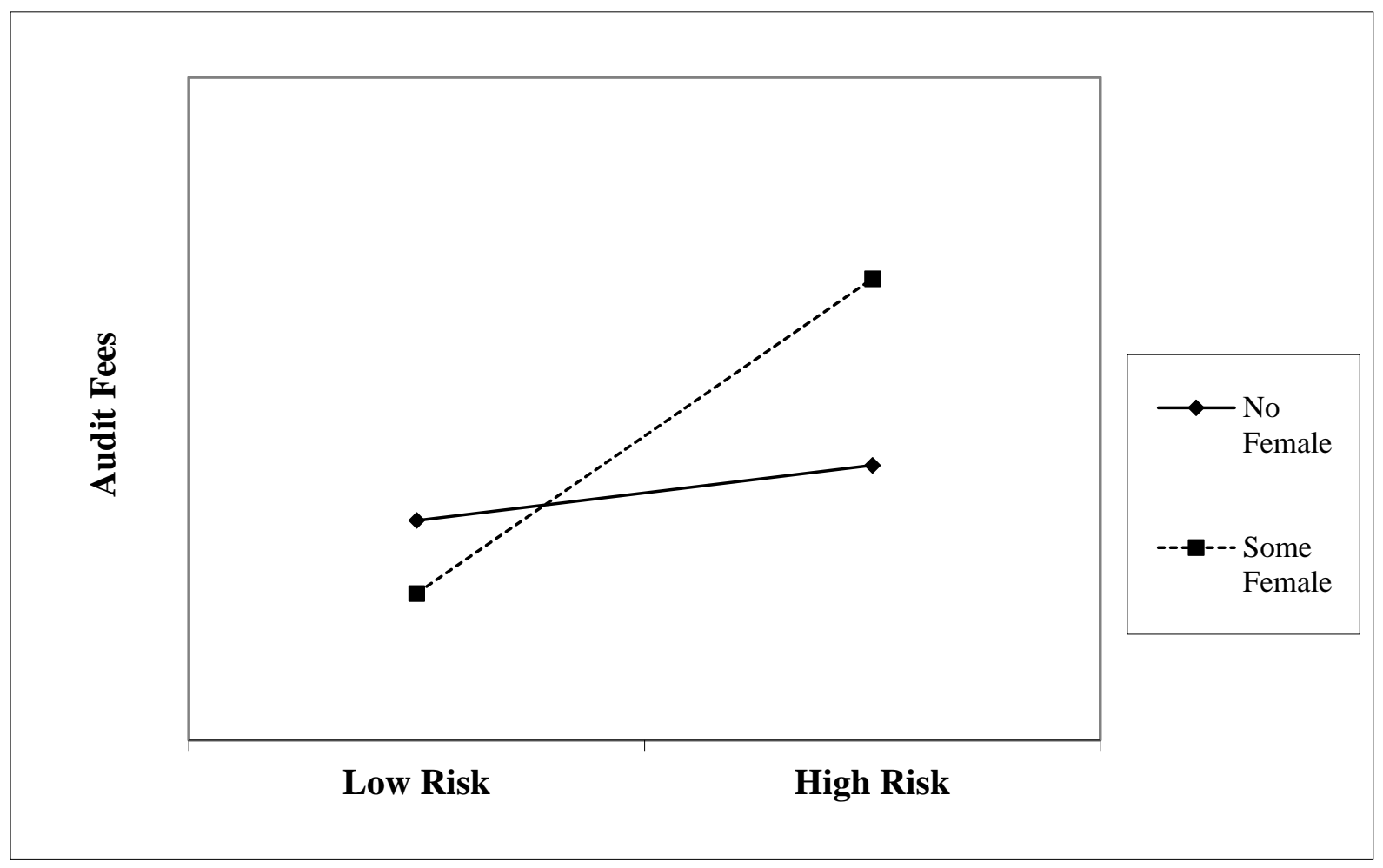


Figure 4. Interaction Effect of Female Representation on the Audit Committee with Complexity in Determining Audit Fees

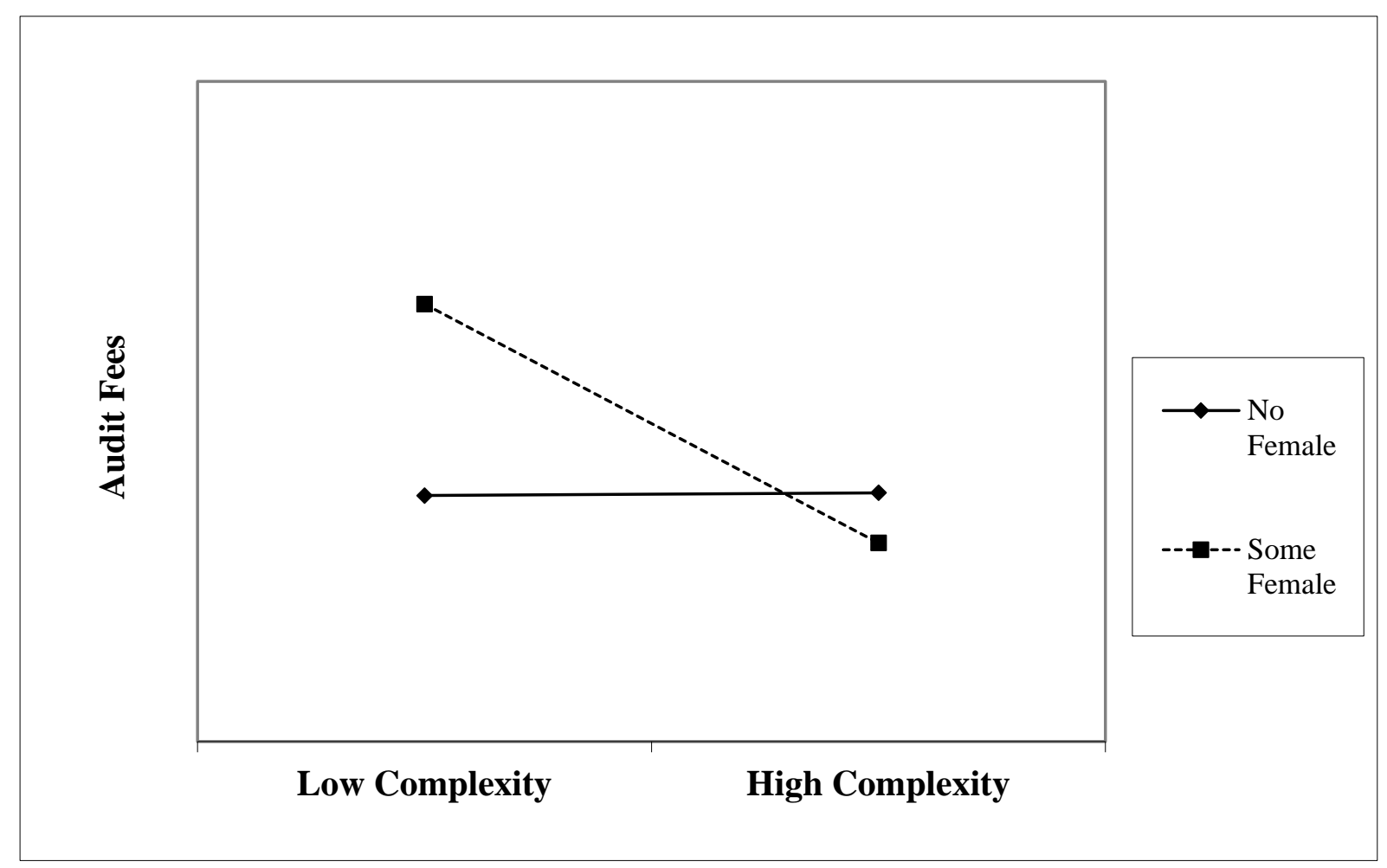

